\title{
Morphological and genetic differentiation of Bufo toads: two cryptic species in Western Europe (Anura, Bufonidae)
}

Jan W. Arntzen ${ }^{1}$, Jacob McAtear ${ }^{1}$, Ernesto Recuero ${ }^{2,3}$, Janine M. Ziermann ${ }^{1,4}$, Annemarie Ohler ${ }^{5}$, Jacques van Alphen ${ }^{1}$, Iñigo Martínez-Solano 6,7,8

${ }^{1}$ Naturalis Biodiversity Center, P.O. Box 9517, 2300 RA Leiden, The Netherlands

${ }^{2}$ Museo Nacional de Ciencias Naturales, CSIC, cl José Gutiérrez Abascal, 2, 28006 Madrid, Spain

${ }^{3}$ present address: Departamento de Ecología de la Biodiversidad, Instituto de Ecología, Universidad Nacional Autónoma de México, Ap. Postal 70-275, Ciudad Universitaria, México DF, 04510, Mexico

${ }^{4}$ present address: Dept. of Anatomy, Howard University, College of Medicine, 520 W St. NW, Washington DC 20059, USA

${ }^{5}$ Muséum national d'Histoire naturelle, Département Evolution et Systématique, UMR 7205 CNRS Origine, Structure et Évolution de la Biodiversité, 25 rue Cuvier, CP 30, 75005 Paris, France

${ }^{6}$ Instituto de Investigación en Recursos Cinegéticos (IREC), CSIC-UCLM-JCCM Ronda de Toledo, s/n 13071 Ciudad Real, Spain

${ }^{7}$ present address: CIBIO (Centro de Investigação em Biodiversidade e Recursos Genéticos), Rua Padre Armando Quintas, s/n, 4485-661 Vairão, Portugal

${ }^{8}$ E-mail: inigomsolano@gmail.com

Key words: Bufo bufo, Bufo spinosus, Common toad, contact zone, France, mitochondrial DNA, morphometrics, nuclear DNA

\begin{abstract}
The Common toad Bufo bufo sensu lato is a widespread, morphologically conserved taxon. Recent studies have uncovered deep genetic differentiation between population groups, highlighting the need to revise the current taxonomy of the group and recognize additional species. Here we investigate patterns of variation in molecular (a mitochondrial DNA restriction enzyme assay and sequence data for two nuclear DNA fragments totalling $979 \mathrm{bp}$ ) and 17 morphological variables in Northern France where two of these groups meet (B. bufo sensu stricto and B. spinosus), in order to delineate their contact zone and uncover characters that would allow discrimination of the two taxa. Mitochondrial DNA data show an abrupt transition from areas where $B$. bufo is present to those inhabited by B. spinosus, with a narrow area of overlap east of the city of Caen. Morphometric characters, particularly those related to the positioning of the parotoid glands and metatarsal tubercle shape and size, proved useful in discriminating between species (AUC $\geq 0.97$, kappa $\geq 0.79$ ). We then used the differentiating character states to allocate over 300 museum specimens from Western Europe to either species with consistent results, including comparable values of AUC and kappa of the identification models, indicating that models could successfully be applied across datasets. We summarize available evidence relevant to the delineation of the distribution of $B$. bufo and B. spinosus in France and discuss the characters differentiating both species in an evolutionary context. In view of
\end{abstract}

the observed morphological and genetic differentiation and the absence of unequivocal evidence for widespread hybridization we support the view that $B$. bufo and $B$. spinosus are best considered different species. Finally, we propose that 'parotoids in parallel position' and a thin and smooth skin are derived character states for $B$. bufo over the northern part of its range.

\section{Contents}

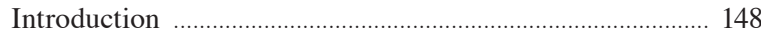

Material and methods ................................................................. 148

Molecular identification and delineation

of the contact zone ........................................................... 148

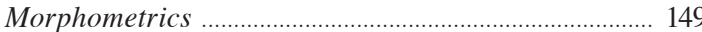

Results ..................................................................................... 151

Molecular identification and delineation

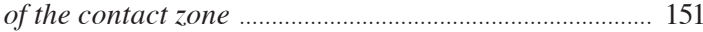

Geographical distribution ................................................. 151

Morphological differentiation and identification ........ 152

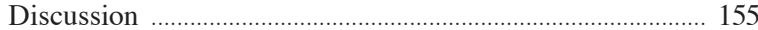

Species differentiation, identification

and taxonomic status .................................................... 155

Evolutionary patterns and puzzles ................................. 157

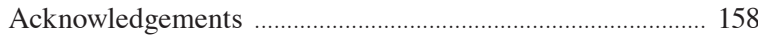

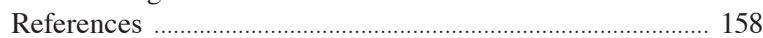

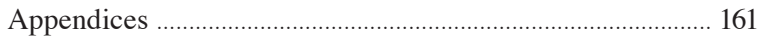




\section{Introduction}

The range of the Common toad Bufo bufo (Linnaeus, 1758) sensu lato stretches from Morocco in the southwest to near Lake Bajkal, Russia, in the east. In Scandinavia it is found north of the Arctic Circle. It is absent from all major Mediterranean islands except Sicily and there are also populations in the British islands, although it is not present in Ireland. Closely related Eurasian species are B. eichwaldi Litvinchuk, Borkin, Skorinov and Rosanov, 2008 and B. verrucosissimus (Pallas, 1814) in the Caucasus, with ranges adjacent to the Caspian Sea and the Black Sea, respectively. Recent work demonstrates the existence of two genetically differentiated, western and eastern groups within the Common toad. The western group conforms to B. spinosus Daudin, 1803 and is distributed in Northern Africa (from Morocco to Tunisia), Iberia and a large part of France. The eastern group conforms to B. bufo (Linnaeus, 1758) and is distributed from Northern and Eastern France to deep into Scandinavia and Russia. It occurs in the Northern Mediterranean region other than the Iberian Peninsula. The sister group of $B$. bufo is not $B$. spinosus but $B$. verrucosissimus (Recuero et al., 2012). The molecular genetic differentiation between $B$. bufo and $B$. spinosus is deep, with a sequence divergence of $7.0 \%$ at mtDNA (uncorrected p-distance at the combined $16 \mathrm{~S}$ and cytb genes; Recuero et al., 2012). With respect to nuclear DNA, allozymes show deep differentiation too (García Porta et al., 2012, Arntzen et al., 2013), whereas two out of the four nuclear genes studied by Recuero et al. (2012) are species diagnostic (the genes $B D N F$ and RPL3). The latter study also found shared alleles in the genes POMC and $C X C R 4$, although it is as yet unclear whether this results from limited introgression or incomplete lineage sorting (Arntzen et al., 2013). The most recent ancestor of the B. bufo - B. spinosus - B. verrucosissimus group is estimated at 9.2 Ma (million years before present) (Recuero et al., 2012). In spite of the deep and long-lasting species differentiation, the species are superficially similar, with no convincing information available on how they could be distinguished by morphology. While contact zones have been approximated based upon expert knowledge (Geniez and Cheylan, 2012: 132) and molecular data (Arntzen et al., 2013), the precise range boundaries and potential extent of overlap between the species are yet to be documented.

We obtained new molecular and morphometric data in two fine-scale transects in Northern France. The aims of the study were to further delineate the contact zone of Bufo bufo and Bufo spinosus with mitochondrial and nuclear DNA markers and to uncover morphological character states that would allow the identification of adult $B$. bufo and B. spinosus. With selected characters we furthermore studied morphological variation in a transect across Western Europe using material from museum collections. On account of the observed morphological differentiation, the deep genetic differentiation, the absence of unequivocal signs of widespread hybridization or introgression of $B$. bufo and B. spinosus in the area we investigated and the sister-group relationship of $B$. spinosus and the $B$. bufo - B. verrucosissimus clade, we conclude that $B$. bufo and B. spinosus are best considered separate species.

\section{Material and methods}

\section{Molecular identification and delineation of the contact zone}

Species identity was determined by mitochondrial DNA restriction fragment length polymorphism (RFLP) analysis. A small tissue sample was taken from either adult toads or tadpoles by clipping off the tip of a toe or of tail, respectively, in five French populations that we knew (Recuero et al., 2012) or anticipated to represent Bufo bufo (a - Audresselles, b - Autreppes and c - Sorques) and B. spinosus (d - Jublains and e - Gizeux) and in two latitudinal transects, with 12 localities from Audresselles to Jublains and 15 localities from Autreppes through Sorques to Gizeux (Fig. 1). The material was stored in $96 \%$ ethanol. Individuals were released at the place of capture. DNA was extracted with the DNeasy Blood and Tissue Kit (Qiagen). We PCR-amplified a fragment of the mitochondrial gene cytochrome-b (cytb), following the procedure described by Recuero et al. (2012). Documented $c y t b$ sequences were searched for the presence of restriction sites with CLC DNA Workbench (CLC Bio, Aarhus, Denmark). Considering expenditure and the size of the expected fragments in Bufo bufo and B. spinosus the restriction enzyme $B c u \mathrm{I}$ was selected. The laboratory procedure followed the recommendations of the distributer (Fermentas, Germany). A mixture of $18 \mu \mathrm{l}$ nuclease free water, $2 \mu \mathrm{l}$ 10X Buffer Tango, $8 \mu \mathrm{l}$ fresh PCR product and $1 \mu \mathrm{l}$ restriction enzyme $(10 \mathrm{u} /$ $\mu \mathrm{l})$ was incubated for two hours at $37^{\circ} \mathrm{C}$. The reaction was stopped by adding $1 \mu \mathrm{l}$ of $0.5 \mathrm{M}$ EDTA (pH 8) to the mixture. Subsequently, the products were loaded 
on a $1 \%$ Agarose gel ( $5 \mu \mathrm{l}$ product loaded; $1 \%$ Agarose in $0.5 \mathrm{XTBE}$ gel) for electrophoretic separation.

Additionally, to further delineate the contact zone and detect the possible presence of admixed populations, two nuclear DNA regions, POMC and RPL3, were amplified and sequenced in ten individuals from each of the five French populations included in the morphometric study (localities a through e, see Fig. 1). Laboratory protocols followed Recuero et al. (2012). Two haplotypes per individual were phased for each of the genes POMC and RPL3 using SeqPHASE (Flot, 2010) and PHASE 2.1.1 (Stephens et al., 2001), under default settings. Haplotype networks were constructed with HaploViewer (available at http://www.cibiv.at/ $\mathrm{greg} /$ haploviewer) using a neighbor-joining tree reconstructed with PAUP* (Swofford, 2001). Sequences from B. verrucosissimus, B. eichwaldi and B. gargarizans Cantor, 1842 from Recuero et al. (2012) were used as outgroups.

\section{Morphometrics}

Seventeen morphological characters of toads from five French localities representing Bufo bufo (Audresselles, 11 males, 11 females; Autreppes, 15 males, 10 females; Sorques, 8 males, 3 females) and $B$. spinosus (Jublains, 13 males, 16 females; Gizeux, 11 males, 7 females) were measured in live toads that were within 18 hours released at the place of capture, from March 2 - April 4, 2012. Species affiliation was on the basis of the DNA profiles (as in results below). We measured snout-urostyle length (SUl), head width (Hw), parotoid length $(\mathrm{Pl})$, parotoid width $(\mathrm{Pw})$, forearm and hindlimb length ( $\mathrm{Fl}, \mathrm{Hl})$, length of the first (innermost) and the third finger including the adjacent tubercle (F11, F31), length of the innermost and the fourth toe, including the adjacent tubercle (T11, T4l), and length and width of the inner metatarsal tubercle (MTl and MTw, Fig. $2 \mathrm{C}$ ). We also measured the anterior (Pda) and posterior parotoid distance (Pdp) to obtain 'parotoid divergence' (Pd=Pda/Pdp; Fig. 2A). Parotoids are frequently asymmetric or oddly shaped. $\mathrm{Pl}$ and $\mathrm{Pw}$ were therefore measured on both the left and the right side of the toad. The other characters were measured along the body axis [SUl and $\mathrm{Pa}$ (see below), Pda and Pdp] or on the right side of the body (the remaining characters). Measurements were taken with a ruler (SUl and $\mathrm{Hl}$; with $0.5 \mathrm{~mm}$ precision), or callipers (with $0.1 \mathrm{~mm}$ precision; for the other characters). Sexes were easy to distinguish in the breeding season from the toad's behaviour and secondary sexual characteristics. Addi- tionally, a photo was taken of the dorsal side of the head. A paper print was then used to measure the character 'parotoid angle' (Pa, Fig. 2B) with the help of a protractor (precision 0.5 degrees). We encountered some difficulties in measuring the relative position of the parotoids, as follows (see also Appendix V). The measurement Pd may be flawed when the position of the anterior or posterior end of the parotoid is unclear and when the parotoids are of unequal length. The measurement $\mathrm{Pa}$ is ambiguous when the parotoids are bean shaped or curved, because it is unclear where exactly to position the tangent (for examples see Muratet, 2008). Note that curved or 'oblique' parotoids such as depicted by Muratet (2008: 181, female) and Arnold et al. (1978: 72) were not encountered in the live material. A few were found in the museum material $(\mathrm{n}=11$ in B. bufo, $12.2 \%$ and $\mathrm{n}=5$ in B. spinosus, $2.3 \%$ ) and in those cases $\mathrm{Pa}$ was measured over two stretches and the mean angle taken, according to the length of both stretches. The measuring of a subsample of $16 \mathrm{~B}$. spinosus (eight males and eight females) was duplicated to assess inter-observer variation $(\mathrm{V})$. $\mathrm{V}$ is defined as the average of $I\left(A_{1}-A_{2}\right) \mid /\left(\left(A_{1}+A_{2}\right) / 2\right)$, in which $A$ is the character state as measured by observers 1 and 2 . Directional asymmetry (DA) of the parotoids was measured the same way and fluctuating asymmetry (FA, small, random differences between sides of bilateral characters; index number 2 in Palmer and Strobeck, 1986) equals IDAI.

In a first, exploratory stage we performed discriminant analysis on the standardized residuals of the regression of $\ln$-transformed morphometric data versus ln-transformed snout-urostyle length, with SPSS 21 (SPSS, 2013). The transformation was done in order to reduce the effect of variation in individual size and to increase the fit to the requirements for such analyses (Sokal and Rohlf, 1981). Four missing values $(0.3 \%$ of the total data) were estimated with linear regression against SUl. The following, more focused analyses were with logistic regression for males and females separately. The fit of statistical models to the data was expressed with the area-under-the-curve statistic (AUC) and with Cohen's kappa (k, Cohen, 1960). To obtain criteria for species identification from untransformed data (that can be readily applied in the field) we described the size and the shape of the metatarsal tubercle $($ MTsize $=\mathrm{MTl} / \mathrm{SUl}$, MTshape $=$ $\mathrm{MTw} / \mathrm{MTl}$ ) and the positioning of the parotoids (Pa and $\mathrm{Pd}$ ).

The validity of the obtained criteria for morphological species identification was assessed through the 


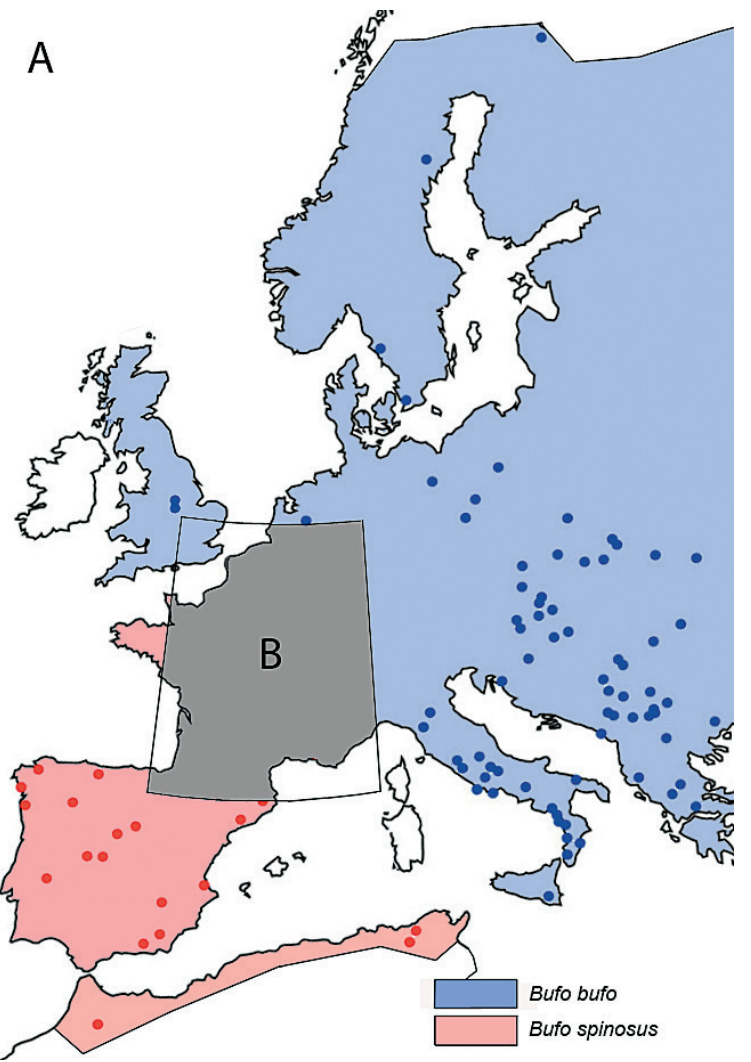

Fig. 1. A: Distribution of Bufo toads across Western and Central Europe. Populations identified with molecular data are shown by blue dots for Bufo bufo and by red dots for B. spinosus, from Recuero et al. (2012). The species' blanket distribution is shown with blue and red shades, after Sinsch et al. (2009). For a comprehensive overview of the available data see Appendix VIII.

B: Sampling localities for Bufo toads in France and adjacent areas. Populations subjected to morphological analyses are: a) Audresselles, b) Autreppes, c) Sorques, d) Jublains and e) Gizeux. Two transects studied for mtDNA RFLP fragments run

analysis of preserved adult toads from 40 localities across Western Europe, as available at our home institutions, namely the Naturalis Biodiversity Center, Leiden (RMNH, $\mathrm{n}=67$ in three populations), the Muséum national d'Histoire naturelle, Paris (MNHNP, n=43 in ten populations) and the Museo Nacional de Ciencias Naturales, Madrid (MNCN, $\mathrm{n}=196$ in 27 populations) (Appendix I). Sex of the specimens was determined on secondary sexual characters or direct observation of the gonads. In addition to measuring the body size, parotoids and metatarsal tubercle we scored the spines on the cheek with the use of five classes (absent, light,

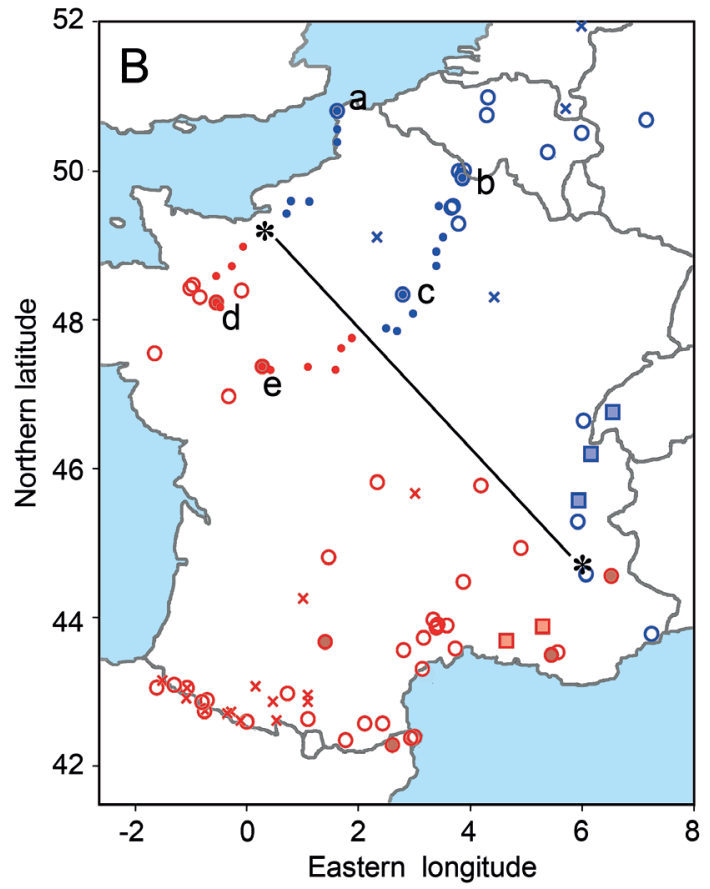

from Audresselles to Jublains with 12 localities and from Autreppes, through Sorques to Gizeux with 15 localities (small round symbols). Two localities shown with an asterisk have mtDNA haplotypes for both species (Moyaux in Northwestern France, present paper, and Saint Bonnet en Champsaur in Southeastern France, Recuero et al., 2012). Other populations with mtDNA identifications are shown by open round symbols (García-Porta et al., 2012; Recuero et al., 2012). Populations additionally identified with nDNA are shown by filled round symbols (Recuero et al., 2012; present paper). Five populations identified with allozyme genetic data are shown by square symbols (data from Lüscher et al., 2001) and localities with museum material are shown by crosses (see also Appendix I). Toads from localities northeast of the diagonal line are identified as $B$. bufo and those to the southwest of the line as $B$. spinosus.

medium, strong and very strong, as in Appendix VII). However, scoring this character raised discussions among observers and we noted that the keratin spines may be related to reproductive state or sex of the specimens and also diminish with the shedding of the skin in preserved material and presumably in the field also. Finally, we measured $\mathrm{Pa}$ and $\mathrm{Pd}$ in 23 adult toads from published imagery (Muratet, 2008) and we reanalyzed data on the degree to which Bufo bufo and B. spinosus have smooth or spined warts, as originally recorded by De Lange (1973), using the same material that is deposited at the Leiden collection. 
A

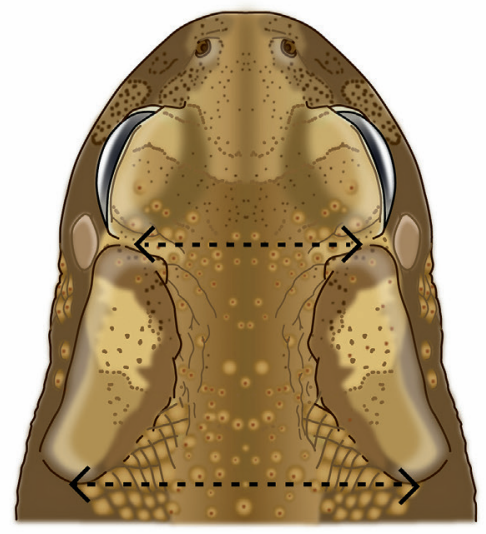

Parotoid divergence ( $\mathrm{Pd}=\mathrm{Pda} / \mathrm{Pdp})$. The anterior and posterior parotoid distances Pda and Pdp are shown by top and bottom arrows, respectively.
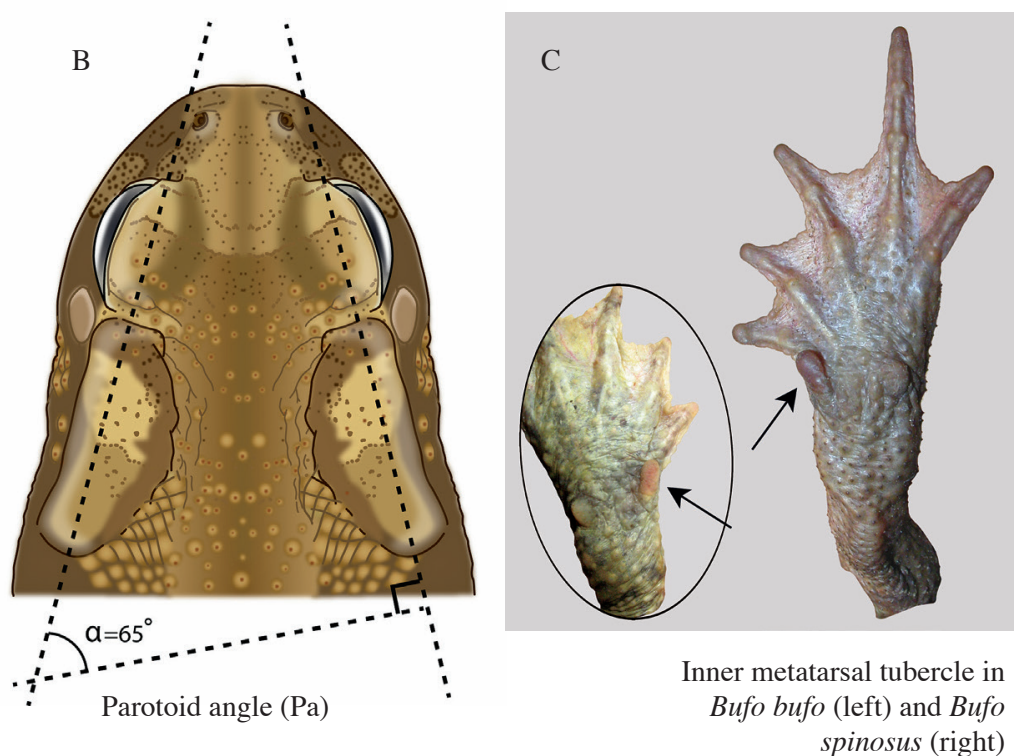

Fig. 2. Key characters in the morphological identification of B. bufo and B. spinosus toads. Parotoid positioning documented with parotoid divergence $(\mathrm{Pd}=\mathrm{Pda} / \mathrm{Pdp}, \mathrm{A})$ and parotoid angle $(\mathrm{Pa}, \mathrm{B})$. In this case, a parotoid angle of $65^{\circ}$ would suggest this individual is a $B$. spinosus. C - inner metatarsal tubercle in B. bufo (left) and B. spinosus (right). Imagery from Muratet (2008) with permission. Unfortunately, the sex of both toads went unrecorded (J. Muratet, pers. comm.).

\section{Results}

\section{Molecular identification and delineation of the contact zone}

Different restriction profiles of $c y t b$ were obtained, one with two fragments of ca. 300 and 500 base pairs (bp) long and one with three fragments of ca. 100, 200 and $500 \mathrm{bp}$ long (see Appendix II). The fragment sizes correspond to 86, 198 and 438 bp in B. bufo and 284 and $438 \mathrm{bp}$ in $B$. spinosus in two randomly selected sequences for these species in GenBank. Out of 27 populations in the two transects studied (Fig. 1), 15 were equated with $B$. bufo, 11 were equated with $B$. spinosus and one population contained both types. This was locality 'Moyaux' $(49.2 \mathrm{~N}, 0.3 \mathrm{E})$ where we found $B$. bufo type mtDNA six times and B. spinosus type mtDNA two times.

We obtained 50 new sequences of POMC (472 bp) and RPL3 (507 bp) from ten individuals of each of the five French populations analyzed for morphometric characters (GenBank accession numbers KF745897KF745924). These were analyzed alongside sequence data published by Recuero et al. (2012). In POMC we found 17 haplotypes, five of them exclusive of the outgroups (Bufo gargarizans and B. eichwaldi). Of the remaining 12, two were shared between $B$. bufo and $B$. verrucosissimus, two were exclusive of $B$. spinosus, five were exclusive of $B$. bufo and the remaining three haplotypes were shared between $B$. spinosus and $B$. bufo in Audresselles $(\mathrm{n}=1)$, Autreppes $(\mathrm{n}=5)$ and Sorques $(n=6)$, plus one toad from Erloy, close to Autreppes, reported by Arntzen et al. (2013) (see also Appendix VIII). In RPL3 we found 57 haplotypes. Allele sharing across species was limited to $B$. bufo and $B$. verrucosissimus (one haplotype), with 15 haplotypes exclusive of $B$. bufo, 29 exclusive of $B$. spinosus, two exclusive of $B$. verrucosissimus and the remaining ten from the outgroups B. eichwaldi (seven haplotypes) and B. gargarizans (three haplotypes, Fig. 3).

\section{Geographical distribution}

The available data on the occurrence of $B$. bufo and $B$. spinosus in and around France are shown in Fig. 1. The mtDNA signature over two transects suggest that these species have parapatric ranges. A straight line can be drawn that approximates the mutual species border, from Caen at the Atlantic coast to Lyon in the upper Rhone valley, with Bufo bufo in the Northeast and B. spinosus in the Southwest of France. With respect to nuclear DNA data, RPL3 is consistent with 


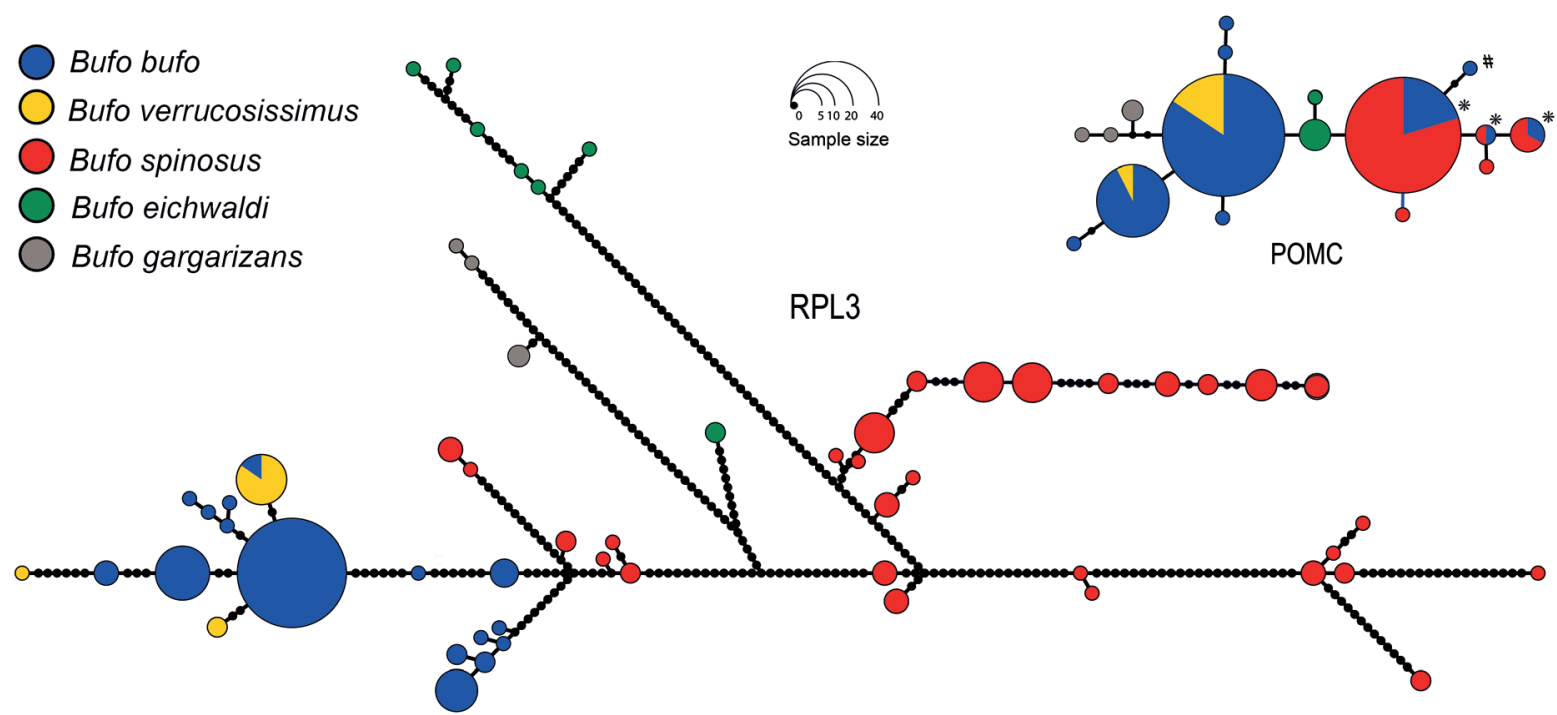

Fig. 3. Haplotype networks for POMC and RPL3 in the Bufo bufo species group (colored by species, based on mtDNA profiles). Circles are proportional to sample size (see scale). Asterisks mark POMC haplotypes that are shared between $B$. spinosus and B. bufo. The symbol "\#" highlights a "spinosus-like" allele that was found in an individual from the United Kingdom (BB04, see text).

mtDNA and morphometric data, whereas POMC alleles are shared across species in a wide area including the localities of Audresselles, Autreppes, Erloy and Sorques (B. bufo), and the French localities of Jublains, Gizeux, Beauzelle and La Manouesse, plus the Iberian populations of Capileira, A Pobra do Caramiñal, Portalegre, Laguna Grande de Gredos and Sadernes, and the north African localities Ifrane and Beni M'Tir (B. spinosus). Since nucleotide variation in $P O M C$ is low, with all haplotypes differing by a maximum of eight mutations, and because there is no clear geographic signal in the patterns of allele sharing, we conclude this most likely reflects incomplete lineage sorting rather than introgression or hybridization (as in marker CXCR4 in Recuero et al., 2012, see Arntzen et al., 2013). For a comprehensive picture on the distribution of the four species in the Bufo bufo species group see Appendix VIII.

\section{Morphological differentiation and identification}

In discriminant analysis of both sexes of both species, the percentage of variance explained was $80.0 \%$ at the first axis and $15.8 \%$ at the second axis. The first axis had high loadings of the characters describing the positioning of the parotoids and the length and width of the metatarsal tubercle and proved useful for discrimination between the species (AUC $=0.94 \pm 0.022$, kappa $=0.73$ ). The second axis had high loadings of the characters describing leg- and toe-length and proved useful for discrimination of the sexes (AUC $=$ $0.73 \pm 0.050, \mathrm{kappa}=0.67)$. Inter-observer variation (V) was highest in the characters related to the metatarsal tubercle and the parotoids $(5.2 \%<\mathrm{V}<8.6 \%)$, medium in the digit characters $(3.6 \%<\mathrm{V}<6.2 \%)$ and low in the other characters $(1.9 \%<\mathrm{V}<3.5 \%)$. Directional asymmetries at $\mathrm{V}$ and left-right differences in the parotoids ( $\mathrm{Pl}$ and $\mathrm{Pw}$ ) were insignificant. An analysis of variance with 'gender' nested under 'species' indicated that FA was higher in males than in females for $\mathrm{Pl}(\mathrm{P}<0.05)$ and marginally significant in $\mathrm{Pw}$ $(0.05<\mathrm{P}<0.10)$.

Logistic regression analyses with the characters SUl, Pa, Pd, MTsize and MTshape available for selection yielded well-fitting models for both sexes (AUC $\geq$ 0.97 , kappa $\geq 0.79$ ). The parotoid - and metatarsal tubercle measurements analyzed in isolation yielded lower, but by and large respectable model fit values (Table 1A; 'respectable scores' are here defined as AUC $>0.9$ and kappa $>0.7$ ). For the museum material the logistic regression analyses with the characters SUl, Pa, Pd, MTsize and MTshape available for selection also yielded well-fitting models for both sexes $(\mathrm{AUC}=0.98$, kappa $\geq 0.88)$. The parotoid and metatarsal tubercle measurements analyzed as separate sets yielded slightly lower model fit values with AUC 
Table 1. Logistic regression models to distinguish (A) live Bufo bufo and B. spinosus in Northern France and (B) museum material of these species from across Western Europe. Either five variables were available for selection under a stepwise procedure (left panel) or variables were entered per character set (right panel). Note that under A body size (SUl) does not significantly contribute to species identification. Model fit is shown by AUC and kappa-values, in boldface type when values are respectable (AUC >0.9, kappa >0.7). N.s. = not selected. Example: the formula $\mathrm{p}=(1 /(1+\exp (-0.274 * \mathrm{~Pa}-394.830 *$ MTsize-31.596*MTshape+12.507 $)))$ calculates the probability (p) that a male toad is B. bufo.

A - Live toads in Northern France

\begin{tabular}{|c|c|c|c|c|c|c|}
\hline \multirow{3}{*}{ Morphometric variable } & \multicolumn{2}{|c|}{ Full model } & \multicolumn{4}{|c|}{ Model per character set } \\
\hline & \multirow[b]{2}{*}{ Males } & \multirow[b]{2}{*}{ Females } & \multicolumn{2}{|l|}{ Parotoids } & \multicolumn{2}{|c|}{ Metatarsus tubercle } \\
\hline & & & Males & Females & Males & Females \\
\hline SUl & n.s. & n.s. & & & & \\
\hline $\mathrm{Pa}$ & -0.274 & n.s. & -0.205 & -0.113 & & \\
\hline $\mathrm{Pd}$ & n.s. & -20.635 & 1.080 & -10.968 & & \\
\hline MTsize & 394.830 & 288.545 & & & 142.592 & 273.790 \\
\hline MTshape & -31.596 & n.s. & & & -21.609 & -8.340 \\
\hline Constant & 12.507 & -0.973 & 13.513 & 16.530 & 3.268 & -11.593 \\
\hline \multicolumn{7}{|l|}{ Model fit } \\
\hline AUC & 0.98 & 0.97 & 0.91 & 0.89 & 0.93 & 0.91 \\
\hline AUC standard error & 0.012 & 0.024 & 0.046 & 0.049 & 0.031 & 0.045 \\
\hline Kappa & 0.86 & 0.79 & 0.76 & 0.70 & 0.62 & 0.75 \\
\hline \multicolumn{7}{|c|}{ Model fit when applied to museum material } \\
\hline AUC & 0.95 & 0.93 & 0.89 & 0.90 & 0.89 & 0.85 \\
\hline AUC standard error & 0.016 & 0.022 & 0.026 & 0.025 & 0.026 & 0.036 \\
\hline Kappa & 0.74 & 0.61 & 0.52 & 0.62 & 0.55 & 0.52 \\
\hline
\end{tabular}

B - Museum material from across Western Europe

\begin{tabular}{|c|c|c|c|c|c|c|}
\hline \multirow{3}{*}{ Morphometric variable } & \multicolumn{2}{|c|}{ Full model } & \multicolumn{4}{|c|}{ Model per character set } \\
\hline & \multirow[b]{2}{*}{ Males } & \multirow[b]{2}{*}{ Females } & \multicolumn{2}{|l|}{ Parotoids } & \multicolumn{2}{|c|}{ Metatarsus tubercle } \\
\hline & & & Males & Females & Males & Females \\
\hline SUl & 0.340 & 0.141 & 0.284 & 0.123 & 0.270 & 0.179 \\
\hline $\mathrm{Pa}$ & n.s. & -0.188 & -0.084 & -0.147 & & \\
\hline $\mathrm{Pd}$ & -35.409 & n.s. & -23.588 & -1.665 & & \\
\hline MTsize & 227.096 & 168.869 & & & 205.355 & 160.347 \\
\hline MTshape & n.s. & -16.392 & & & -5.438 & -11.675 \\
\hline Constant & -6.397 & 0.454 & 7.261 & 1.592 & -27.022 & -17.408 \\
\hline \multicolumn{7}{|l|}{ Model fit } \\
\hline AUC & 0.98 & 0.98 & 0.93 & 0.94 & 0.96 & 0.96 \\
\hline AUC standard error & 0.010 & 0.009 & 0.019 & 0.019 & 0.013 & 0.017 \\
\hline Kappa & 0.88 & 0.89 & 0.77 & 0.71 & 0.82 & 0.75 \\
\hline \multicolumn{7}{|c|}{ Model fit when applied to live material } \\
\hline AUC & 0.92 & 0.97 & 0.89 & 0.91 & 0.92 & 0.94 \\
\hline AUC standard error & 0.042 & 0.022 & 0.048 & 0.046 & 0.035 & 0.036 \\
\hline Kappa & 0.76 & 0.79 & 0.63 & 0.74 & 0.65 & 0.83 \\
\hline
\end{tabular}



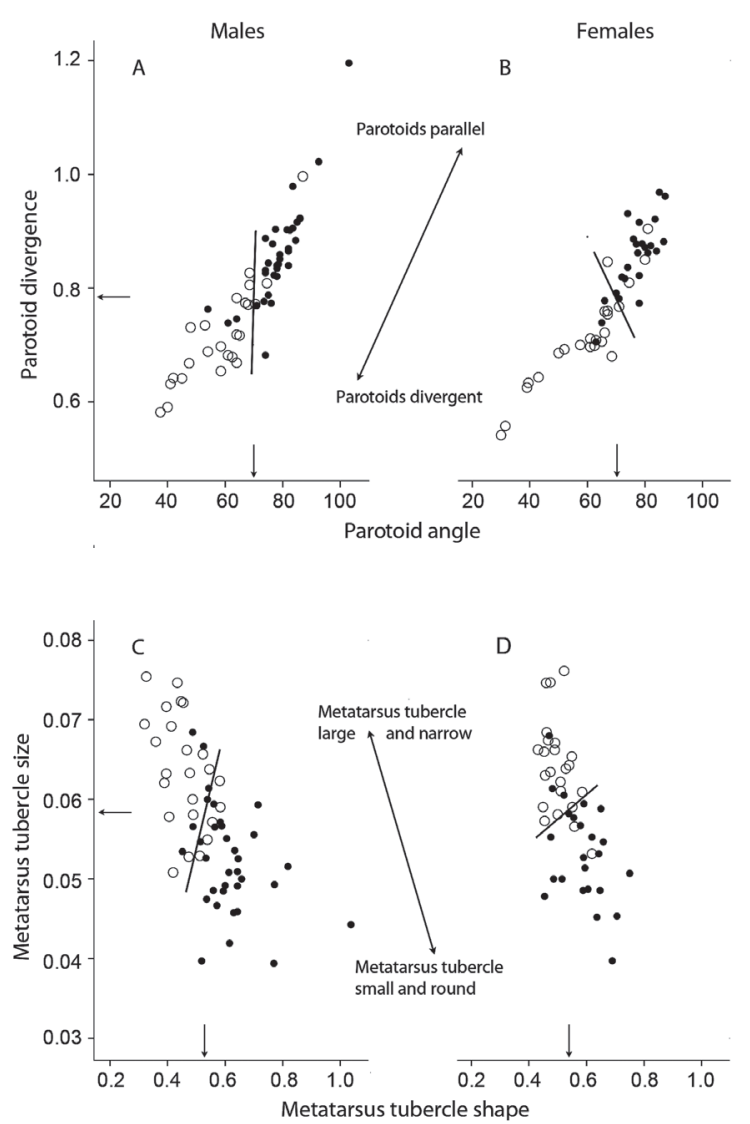

Fig. 4. Bivariate plot of parotoid (top) and metatarsal tubercle (bottom) character sets in Bufo bufo (solid dots) and B. spinosus (open dots) from Northern France. Males are shown on the left and females on the right. The solid lines show species separation as determined by logistic regression analyses; for formulas and model fit see Table 1. Arrows indicate $B$. bufo versus B. spinosus classification criteria (see Discussion).

$\geq 0.93$ and kappa $\geq 0.71$ (Table 1B). Models for the two data sets were not dissimilar, except that the parameter SUl was not included for the live material and was included for the museum material. When the models derived for live toads were applied to the museum material and vice versa model fit was somewhat less good than in the original models, with a drop of 1-6 percentage points in AUC-values.

Seen from the tip of the snout, the parotoids in $B$. spinosus are widely divergent whereas in $B$. bufo they are positioned in parallel or slightly divergent (Fig. 4AB). In B. bufo the metatarsal tubercle is small and in B. spinosus it is larger (Fig. 2C); in males the tubercle is more round in B. bufo and more narrow in B. spino-
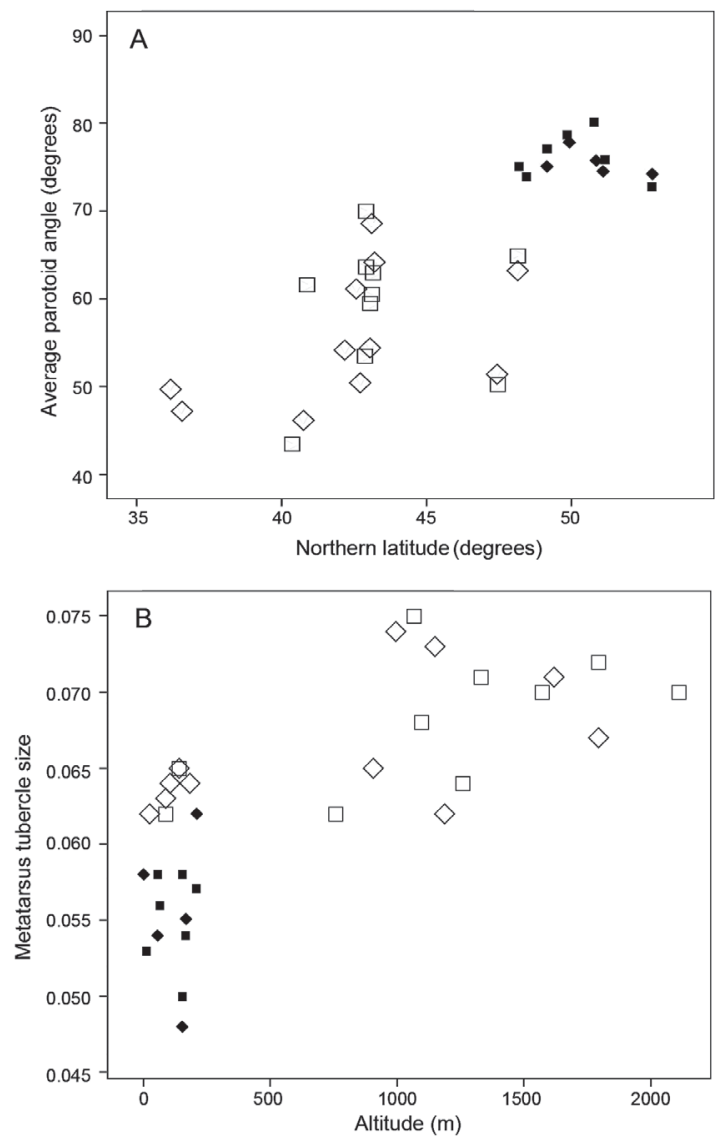

Fig. 5. Variation in A) parotoid angle as a function of degrees northern latitude and B) size of the metatarsus tubercle as a function of altitude observed in male (diamond symbols) and female (square symbols) in Bufo bufo (small solid symbols) and $B$. spinosus populations (large open symbols). Shown are averages for populations with a sample size $\geq 5$, as in Appendix IV.

sus (Fig. 4CD; see Appendix III for absolute values). The analysis of the character $\mathrm{Pa}$ in isolation showed that the cut-off point for the species is $70^{\circ}$ in males $(-0.197 * \mathrm{~Pa}$, constant $=13.765 ;$ AUC $=0.91 \pm 0.045$, kappa $=0.76)$ as well as in females $(-0.205 * \mathrm{~Pa}$, constant $=14.371 ; \mathrm{AUC}=0.88 \pm 0.051$, kappa $=0.66$; for an example of a logistic regression equation see the footnote to Table 1).

Intraspecific variation in $\mathrm{SU}, \mathrm{Pa}, \mathrm{Pd}, \mathrm{MTsize}$ and cheek spines is higher in B. spinosus than in B. bufo from Northwestern Europe. A data summary for field and museum material with $\mathrm{N} \geq 5$ per population and sex is reported in Appendix IV. Visual inspection of the data against the latitudinal and altitudinal gradi- 
ents showed no patterns, other than a tendency in $B$. spinosus from the south of Spain to have widely diverging parotoids $(\mathrm{Pa}<50)$ and for metatarsal tubercles to increase with altitude (Fig. 5).

Twenty-three adult toads for which dorsal images were published (Muratet, 2008; 12 B. bufo and 11 B. spinosus) were identified using the parotoid characters $\mathrm{Pa}$ and Pd with the formulae presented in Table 1. Nineteen toads were classified correctly $(83 \%$, AUC $=0.97 \pm$ 0.030 ; kappa $=0.66$ ). Finally, statistical analysis with Fisher's exact test of the data published by De Lange (1973) on museum preserved toads from Western Europe indicates that $B$. spinosus is more heavily spined than $B$. bufo (males $P<0.01$, females $P<0.0001$ ) and that $B$. bufo females are more heavily spined than males $(P<0.001$; in B. spinosus $P>0.2$; Appendix VI).

\section{Discussion}

Species differentiation, identification and taxonomic status

Lüscher et al. (2001) studied 24 toad populations in and around Switzerland at ten allozyme loci and compared these with four Mediterranean populations from France and Italy. Genetic differentiation was minimal, with the exception of two Southern French populations that showed a Nei's genetic distance of ca. 0.19 relative to the remainder. We classify these populations as $B$. spinosus and the others as B. bufo (Fig. 1B). The deep genetic differentiation of B. bufo and B. spinosus was further highlighted by a variety of molecular markers (García-Porta et al., 2012; Recuero et al., 2012). The available molecular data allow the approximate delimitation of the contact zone of B. bufo and B. spinosus across France, from Caen at the Atlantic coast, through the upper Rhone valley near Lyon, to the Mediterranean Cote d'Azur (Fig. 1B). A more detailed survey along the mutual range border of $B$. bufo and $B$. spinosus is in progress (Arntzen et al., in prep.).

Allele sharing for B. bufo and B. spinosus was not observed at the RPL3 locus and species specific mtDNA haplotypes were not found in syntopy, other than at the species contact zone. At $P O M C$ we recorded a different pattern. Firstly, alleles typical for B. spinosus (Arntzen et al., 2013) were found in B. bufo and not the other way round; this asymmetry is statistically significant (G-test of independence, $\mathrm{P}<0.001)$. Secondly, these 'spinosus-alleles' are found not just relatively close to the species contact zone (frequency $30 \%$ at
Sorques), but also further away (frequency $25 \%$ at $\mathrm{Au}-$ treppes). An intriguing possibility supported by these observations is that the 'spinosus-alleles' carried by $B$. bufo in Northeastern France constitute 'genetic footprints' (sensu Scribner and Avise, 1993), with interspecific gene flow in the direction of the invading species (Currat et al., 2008). This would indicate that B. spinosus previously had a wider distribution and was subsequently superseded by $B$. bufo over a part of its range, i.e., Northeastern France and beyond. If this interpretation is correct, it would be worthwhile to also test for the past presence of B. spinosus in the United Kingdom, because we observed one copy of the POMC 'spinosus-allele' in Audresselles at the French side of the Chanel and, moreover, one 'spinosus-like' allele at the locality Wymeswold near Leicester in the United Kingdom (Fig. 3; sample BB04 in Recuero et al., 2012). However, more data are required before we can rule out the possibility of incomplete lineage sorting to explain allele sharing at $P O M C$.

The measurements on live toads in populations at either side of the contact zone confirm that $B$. bufo and $B$. spinosus are morphologically differentiated. With just the panel of 17 scaled morphometric characters it would be more compelling to identify a given individual to the species than to determine its gender. Employing the characters describing the size and the shape of the inner metatarsal tubercle (MTsize and MTshape) and the positioning of the parotoids ( $\mathrm{Pa}$ and $\mathrm{Pd})$, largely correct species identification is achieved (Table 1). The AUC and kappa values for the various models indicate that species identification based on either the parotoids or the metatarsal tubercle works about equally well (but less well than the data in combination). It is important to note that SUl was not included in the models for this area, indicating that body size does not need to be known for reliable morphometric species identification. Conversely, the models for the museum material all included SUl. The difference can be explained by the wide inverse Bergmannian cline in body size across the B. bufo / B. spinosus range (Cvetkovic et al., 2008; Appendix IV), the effect of which is substantial in the transect spanning Western Europe from $36^{\circ}-53^{\circ}$ northern latitude, but not noticeable in the sampling area of Northern France that spans less than four degrees. Despite the wide cline, the models derived for live toads in Northern France are highly transferable, i.e., they yield a good fit when applied to museum material from across Western Europe (AUC range 0.85-0.95) and vice versa (AUC range 0.89-0.97; Table 1). 


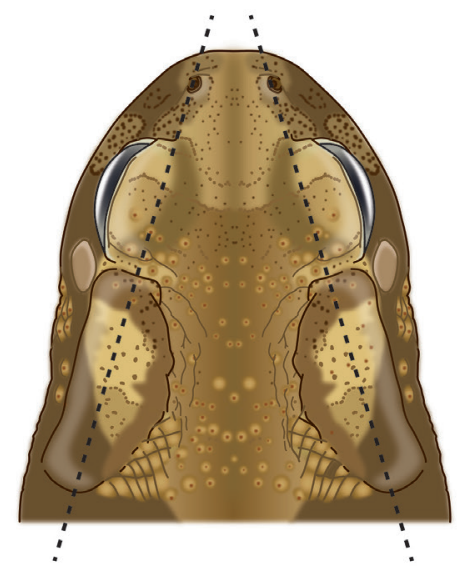

divergent

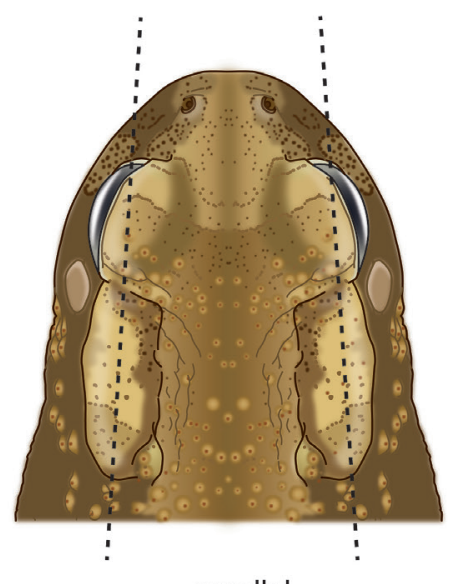

parallel

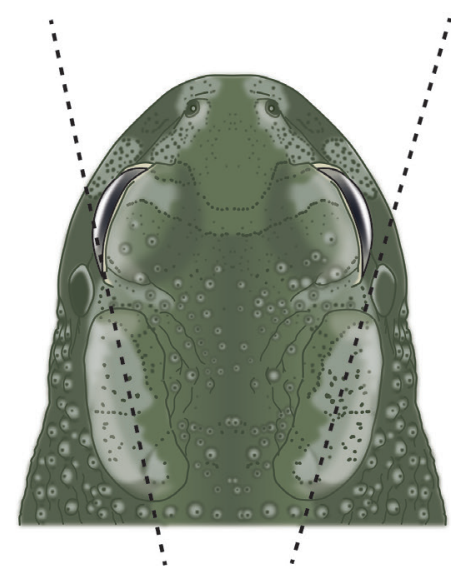

convergent

Fig. 6. The positioning of parotoids in toads from Western Europe is, seen in anterior to posterior direction, either divergent (left, Bufo spinosus), near-parallel or slightly divergent (middle, Bufo bufo) or convergent (right, Bufo viridis, shown for comparison; see also Arnold $e$ t al., 1978). Inter- and intra-specific variation in head shape and parotoid size, shape and positioning of the two former species is illustrated in Appendix V, as observed in Northern France. For morphometric variation over Western Europe see Fig. 5 and Appendix IV.

The parotoids are more widely divergent in $B$. spinosus than in B. bufo and the inner metatarsal tubercle is larger in B. spinosus than in B. bufo. In male toads the tubercle is more rounded in $B$. bufo and narrower in B. spinosus. In B. spinosus the metatarsal tubercle may be ovoid or pear-shaped, especially in females. Adult Bufo toads in Northern France can be identified to the species with the following key:

Parotoids in parallel position or slightly divergent, metatarsal tubercle small and round Bufo bufo

Parotoids divergent, metatarsal tubercle large and narrow ........ Bufo spinosus

Morphometric criteria to classify live toads from Northern France as Bufo bufo and not B. spinosus (see also Fig. 4) are:

\begin{tabular}{ll}
\hline Character & Character state \\
\hline Parotoid angle & $\geq 70^{\circ}$ \\
Parotoid divergence & $>0.785$ \\
Metatarsal tubercle size & $<0.0585$ \\
Metatarsus tubercle shape - males & $>0.53$ \\
Idem - females & $>0.54$
\end{tabular}

These diagnostic morphological characters have been highlighted in the literature on anuran systematics before. The inner metatarsal tubercle is recognized as a character of taxonomic importance in e.g., European species of green frogs (genus Pelophylax). The more terrestrial species inhabiting loose soils $P$. lessonae (Camerano, 1882) has a longer and more prominent metatarsal tubercle than the more aquatic species $P$. ridibundus (Pallas, 1771). Whether there is a parallel with differential ecological preferences of $B$. bufo and $B$. spinosus toads remains to be investigated. To the positioning of the parotoids as 'convergent' as observed in Bufo viridis (Laurenti, 1768) and Bufo calamita (Laurenti, 1768) or marginally divergent as in $B$. bufo, we add the character state 'divergent' that is observed in B. spinosus (Fig. 6). Unfortunately, the taxonomically important characters (MTl, MTw, Pa and Pd) are exactly those that show the highest interobserver variation in the field. Moreover, in collection material, preservation can affect the shape of the metatarsal tubercle, e.g., when squeezed if there is not enough space in the jars, and parotoids might get flattened and their edges less neat in preserved toads than in live toads. Nevertheless, the criteria for species identification derived from live material in France appear to be applicable to ethanol-preserved material from across Western Europe, as indicated by high model transferability (Table 1). Allometric effects and geographical or clinal variation may come into play, but affect the identification criteria only marginally.

In addition to the morphological and genetic differences between $B$. bufo and B. spinosus reported 
here, Hemelaar (1988) found a striking difference in life-history between a population of $B$. spinosus from Southern France and populations of B. bufo from Switzerland, Germany, Norway and The Netherlands. They grow much faster and mature after having spent ca. $60 \%$ longer on growth than B. bufo (Hemelaar, 1988), but again, the difference may turn out to be clinal across species instead of abrupt and species-specific, when a wider array of populations is considered (Cvetkovic et al., 2008).

Several studies purported to document species differences were based on the assumption that $B$. spinosus is pan-Mediterranean and $B$. bufo a northern species, which we now know is incorrect. For example, bioacoustic differences were documented for toad populations from Hungary and Greece, with statistically significant differences at six out of seven call parameters (Schneider and Sinsch, 2004; Schneider, 2005). Actually, this suggests the presence of a pronounced geographical variation within $B$. bufo, or perhaps a strong effect of body size (see Cvetkovic et al., 2008; Gingras et al., 2013). Similarly, a high density of cheek warts observed in Italian B. bufo (Lüscher et al., 2001) indicates that this character state is not typical for B. spinosus. Wilkinson et al. (2007) reported that the majority of microsatellite loci developed did not amplify well in Bufo from two French localities that fall within the range of $B$. spinosus. With the benefit of hindsight this may be attributed to the fact that the primers for these microsatellites were developed for $B$. bufo from the United Kingdom (Brede et al., 2001; Brede and Beebee, 2006) and do not amplify well in another species (see also van de Vliet et al., 2012).

On account of the deep genetic differentiation, the absence of unequivocal evidence for hybridization of $B$. bufo and B. spinosus in the area we investigated, the sister-group relationship of $B$. spinosus and the $B$. bufo - B. verrucosissimus clade and the observed morphological differentiation (Arntzen et al., 2013; present paper), we conclude that $B$. bufo and $B$. spinosus are best considered separate species. However, considering that all Mediterranean toad populations were until recently considered Bufo bufo spinosus (e.g., GarcíaPorta et al., 2012), we presume that southern B. bufo resemble $B$. spinosus in morphology, but data are scarce (e.g., De Lange, 1973). Similarly, eight Bufo bufo from the Rhodopi Mountains in Southern Bulgaria had parotoid angles in the B. spinosus range (JvA unpublished data: range $43^{\circ}-68^{\circ}$ and average $59.8^{\circ}$, cf. Figs 4 and 5), which on the criterion from western Europe would classify them as B. spinosus.

\section{Evolutionary patterns and puzzles}

Toads in the B. bufo species group have no aposematic coloration, no particular odours and they do not bite. They have no elongated ribs with protruding epipleural processes as in the salamander Pleurodeles waltl Michahelles, 1830 that function as a concealed weapon, capable of actively piercing through the skin to hurt a predator, even if at the same time hurting itself (Leydig, 1879; Nowak and Brodie, 1978; Heiss et al., 2009). Bufo toads are poor jumpers and do not rely on escape behaviour to defer predators and also they do not use the 'Unken reflex' (Duellman and Trueb, 1986). Aside from an inconspicuous life style their main defence mechanism is the possession of parotoid glands from which they can expel a venomous secretion. Also they employ bladder emptying and inflate their lung and, in doing so, the belly, to defend themselves.

Inspired by the observation that the cheek warts are often the largest and most strongly keratinized ones on a toad's body, we suggest that these devices, along with large adult size, a wide head with diverging parotoids and the capability of puffing itself up, assist to counter predators such as snakes that swallow their prey entirely and have limited gape-width. Elias and Shapiro (1957) proposed that the presence of spines on warts might discourage predators in Bufo americanus (Holbrook, 1836). The particularly well-developed cheek warts with keratinized spines (see specimen MNCN 25647 in Appendix VII) may thus be analogous to the sharp, backward pointing extensions of the quadratum bones ('quadrate hooks', Brodie et al., 1984) in the salamander Echinotriton andersoni (Boulenger, 1892). This hypothesis implies that predation by snakes is currently underestimated and that more species have toads on their menu than just the two grass snakes known to consume toads [Natrix natrix (Linnaeus, 1758) and N. maura (Linnaeus, 1758), see García-París et al., 2004; Sinsch et al., 2009]. To test our scenario geographical variation can be employed as a tool (cf. Durand et al., 2012; Hoso and Hori, 2008). The hypothesis to be tested is that a toad's head is wider, body size larger and cheek warts with keratinized spines more prominent in areas with high densities of bufonivorous snakes. Prey choice experiments with snakes and measurements of rates of successful attacks could be measured on toads differing in these features. However, head width also determines mouth width and thereby the maximum size of prey items that can be swallowed as 
toads don't chew up their prey into pieces. The largest prey reported for B. bufo / B. spinosus are worms, leaches (invertebrates) and among vertebrates lizards, geckos, songbirds and mice (Sinsch et al., 2009). The confounding hypothesis that a wide mouth allows the uptake of larger prey could be tested by studying the menu of toads in northern and southern populations. High levels of fluctuating asymmetry (FA) would not be expected from characters under strong natural selection from predators (Bergstrom and Reimchen, 2003), which runs counter to our observation that parotoid size and shape are highly variable, and fails to explain that FA is higher in males than in females. We consider the study of geographic variation in size and shape of the parotoids and metatarsus tubercle, head width and cheek spines a promising line of research. Bufo spinosus is a suitable species for this study, on account of the geographic variation observed at these characters (Fig. 5, Appendices IV and VII).

While head shape has been considered of taxonomic importance (Blair, 1972), the lack of congruence with a molecular phylogeny (Pyron and Wiens, 2011) suggests that the character is highly evolvable. The outgroup to the $B$. bufo $-B$. verrucosissimus $B$. spinosus clade possesses multiple character states (2/0, 2/2 and $2 / 3$ of Inger, 1973), with a wide skull in $B$. gargarizans, a medium wide skull in $B$. tibetanus Zarevsky, 1926 [note that these taxa are closely related and could not be clearly distinguished by genetic studies (Zhan and $\mathrm{Fu}, 2011)]$ and a narrow skull in Bufo raddei Strauch, 1876 (Ye et al., 1993). Hence, the polarity of character transformation series cannot be determined, supporting the Pyron and Wiens (2011) view. Yet the most parsimonious scenario is that a wide head represents the ancestral condition in the $B$. bufo, $B$. spinosus, $B$. verrucosissimus species group and that a narrow head is a local adaptation in northern B. bufo.

Bufo bufo spinosus is traditionally diagnosed as a Mediterranean taxon with large body size, a parchment-like skin and a dense network of well-developed warts with keratinous spines (De Lange, 1973). The large body suggests a high desiccation tolerance due to a lower surface to volume ratio (Schmidt, 1965), the parchment skin may reduce evaporation and the extensive sculpturing of thickened skin warts may assist passive water uptake (Lillywhite and Licht, 1974, Toledo and Jared, 1993). As many of the warts in Bufo include histological elements that resemble tactile corpuscles (Elias and Shapiro, 1957) they may play a role as sensory organs, but why then the expression of warts would vary geographically we do not know. It has been proposed adaptations to a dry environment have evolved in B. spinosus and Mediterranean $B$. bufo independently (Lüscher et al., 2001; García-Porta et al., 2012). However, as with head width, an alternative scenario is that the reverse conditions of small body size and a thin and smooth skin are local adaptations of northern $B$. bufo.

\section{Acknowledgements}

We thank Bas Blankevoort for the artwork in Figs 2, 6 and Appendix V (copyright Naturalis Biodiversity Center) and M. Calvo and M. Domínguez of the MNCN Herpetology collection for access to the material under their care. Partial funds for this project were provided by the Spanish Ministerio de Ciencia e Innovación (Refs.: CGL2008-04271-C02-01/BOS and CGL2011-28300), Junta de Comunidades de Castilla la Mancha (Ref.: PPII10-0097-4200) and FEDER to IMS, who was a 'Ramón y Cajal' postdoctoral fellow supported by the Spanish Ministerio de Ciencia e Innovación and the Universidad de Castilla la Mancha. ER is supported by a DGAPAUNAM postdoctoral fellowship. JWA, JvA and JM thank the Schure-Beijerinck-Popping fund and the Jan Joost ter Pelkwijkfonds for financial support.

\section{References}

Arnold EN, Burton JA, Ovenden DW. 1978. A Field Guide to the Reptiles and Amphibians of Britain and Europe. London: Collins.

Arntzen JW, Recuero E, Canestrelli D, Martínez-Solano I. 2013. How complex is the Bufo bufo species group? Molecular Phylogenetics and Evolution 69: 1203-1208.

Bergstrom CA, Reimchen TE. 2003. Asymmetry in structural defenses: insights into selective predation in the wild. Evolution 57: 2128-2138.

Beukema W, de Pous P, Donaire-Barroso D, Bogaerts S, GarcíaPorta J, Escoriza D, Arribas OJ, El Mouden EH, Carranza S. 2013. Review of the systematics, distribution, biogeography and natural history of Moroccan amphibians. Zootaxa 3661: $1-60$.

Blair WF. 1972. Evolution in the genus Bufo. Austin: University of Texas Press.

Bogaerts S, Donaire-Barroso D, Pasmans F, Herbert D, Beukema W. 2013. New data on the distribution of Bufo bufo in Tunisia. Herpetology Notes 6: 203-207.

Brede EG, Rowe G, Trojanowski J, Beebee TJC. 2001. Polymerase chain reaction primers for microsatellite loci in the common toad Bufo bufo. Molecular Ecology Notes 1: 308310.

Brede EG, Beebee TJC. 2006. Consistently different levels of genetic variation across the European ranges of two anurans, Bufo bufo and Rana temporaria. Herpetological Journal 16: 265-271. 
Brodie ED, Nussbaum RA, DiGiovanni M. 1984. Antipredator adaptations of Asian salamanders (Salamandridae). Herpetologica 40: 56-68.

Cohen J. 1960. A coefficient of agreement for nominal scales. Educational Psychology Measurement 20: 37-46.

Currat M, Manuel R, Petit RJ, Excoffier L. 2008. The hidden side of invasions: massive introgression by local genes. Evolution 62: 1908-1920.

Cvetkovic D, Tomasevic N, Ficetola GF, Crnobrnja-Isailovic J, Miaud C. 2008. Bergmann's rule in amphibians: combining demographic and ecological parameters to explain body size variation among populations in the common toad Bufo bufo. Journal of Zoological Systematics and Evolutionary Research 47: 171-180.

De Lange L. 1973. A contribution to the intraspecific systematics of Bufo bufo (Linnaeus, 1758) (Amphibia). Beaufortia 21 (280): 99-116.

Duellman WE, Trueb L. 1986. Biology of amphibians. New York: McGraw Hill.

Durand J, Legrand A, Tort M, Thiney A, Michiewicz RJ, Coulon A, Aubret F. 2012. Effects of geographic isolation on anti-snakes responses in the wall lizard, Podarcis muralis. Amphibia-Reptilia 33: 199-206.

Elias H, Shapiro J. 1957. Histology of the skin of some toads and frogs. Novitates of the American Museum of Natural History 1819: 1-27.

Flot JF. 2010. SeqPHASE: a web tool for interconverting PHASE input/output files and FASTA sequence alignments. Molecular Ecology Resources 10: 162-166.

García-París M, Montori A, Herrero P. 2004. Fauna Ibérica. Madrid: Museo Nacional de Ciencias Naturales-Consejo Superior de Investigaciones Científicas.

García-Porta J, Litvinchuk SN, Crochet PA, Romano A, Geniez PH, Lo-Valvo M, Lymberakis P, Carranza S. 2012. Molecular phylogenetics and historical biogeography of the westpalearctic common toads (Bufo bufo species complex). Molecular Phylogenetics and Evolution 63: 113-130.

Geniez PH, Cheylan M. 2012. Les amphibiens et les reptiles du Languedoc-Rousillon et regions limitrophes. Atlas biogéographique. Paris: Biotope - Muséum national d'Histoire naturelle.

Gingras B, Boeckle M, Herbst CT, Fitch WT. 2013. Call acoustics reflect body size across four clades of anurans. Journal of Zoology 289: 143-150.

Heiss E, Natchev N, Salaberger D, Gumpenberger M, Rabanser A, Weisgram J. 2009. Hurt yourself to hurt your enemy: new insights on the function of the bizarre antipredator mechanism in the salamandrid Pleurodeles waltl. Journal of Zoology 280: 156-162.

Hemelaar A. 1988. Age, growth and other population characteristics of Bufo bufo from different latitudes and altitudes. Journal of Herpetology 22: 369-388.

Hoso M, Hori M. 2008. Divergent shell shape as an antipredator adaptation in tropical land snails. American Naturalist 172: 726-732.

Inger RF. 1973. Bufo of Eurasia. Pp. 102-118 in: Blair WF., ed., Evolution in the genus Bufo. Austin: University of Texas Press.

Kutrup B, Yilmaz N, Canakci S, Belduz AO, Doglio S. 2006. Intraspecific variation of Bufo bufo, based on $16 \mathrm{~S}$ ribosomal RNA sequences. Amphibia-Reptilia 27: 268-273.
Leydig F. 1879. Die Rippenstacheln des Pleurodeles waltiii. Archiv für Naturgeschichte 45: 211-234.

Lillywhite HB, Licht P. 1974. Movement of water over toad skin: functional role of epidermal sculpturing. Copeia 1974: 165-171.

Litvinchuk SN, Mazepa GO, Kami HG, Auer M. 2012. Taxonomic status and distribution of common toads in Iran. Herpetological Journal 22: 271-274.

Lüscher B, Grossenbacher K, Scholl A. 2001. Genetic differentiation of the common toad (Bufo bufo) in the Swiss Alps. Amphibia-Reptilia 22: 141-154.

Muratet J. 2008. Identifier les Amphibiens de France métropolitaine. Guide de terrain. Avignonet-Lauragais: Association ECODIV.

Nowak RT, Brodie ED. 1978. Rib penetration and associated antipredator adaptations in the salamander Pleurodeles waltl (Salamandridae). Copeia 1978: 424-429.

Palmer AR, Strobeck C. 1986. Fluctuating asymmetry: measurement, analysis, patterns. Annual Review of Ecology and Systematics 17: 391-421

Pyron RA, Wiens JJ. 2011. A large-scale phylogeny of Amphibia including over 2800 species, and a revised classification of extant frogs, salamanders, and caecilians. Molecular Phylogenetics and Evolution 61: 543-583.

Recuero E, Canestrelli D, Vörös J, Szabó K, Poyarkov NA, Arntzen JW, Crnobrnja-Isailovic J, Kidov AA, Cogălniceanu D, Caputo FP, Nascetti G, Martínez-Solano I. 2012. Multilocus species tree analyses resolve the radiation of the widespread Bufo bufo species group (Anura, Bufonidae). Molecular Phylogenetics and Evolution 62: 71-86.

Schmid WD. 1965. Some aspects of the water economies of nine species of amphibians. Ecology 46: 261-269.

Schneider H. 2005. Bioakustik der Froschlurche. Einheimische und verwandte Arten. Bielefeld: Laurenti-Verlag.

Schneider H, Sinsch U. 2004. Calls and calling behaviour of the common toad, Bufo b. bufo, in Hungary and a comparison with the advertisement call of the giant toad, Bufo b. spinosus. Zeitschrift für Feldherpetologie 11: 187-201.

Scribner KT, Avise JC. 1993. Cytonuclear genetic architecture in mosquitofish populations and the possible roles of introgressive hybridization. Molecular Ecology 2: 139-149.

Sinsch U, Schneider H, Tarkhnishvili D. 2009. Bufo bufo Superspezies - Erdkröten-Artenkreis - taxon bufo (Linnaeus, 1758) - Erdkröte - taxon gredosicola L. Müller und Hellmich 1935 - Gredoserdkröte - taxon spinosus Daudin, 1803 - Riesenerdkröte - taxon verrucosissumus (Pallas, 1811) - Kolchische Erdkröte. Pp. 191-335 in: Grossenbacher K., ed., Handbuch der Reptilien und Amphibien Europas, 5/II. Froschlurche (Anura) II (Hylidae, Bufonidae). Wiebelsheim: Aula-Verlag.

Sokal RR, Rohlf FJ. 1981. Biometry. Second edition. San Francisco: Freeman and Co.

SPSS. 2013. Statistical Package for the Social Sciences. Chicago: SPSS Inc.

Stephens M, Smith N, Donnelly P. 2001. A new statistical method for haplotype reconstruction from population data. American Journal of Human Genetics 68: 978-989.

Swofford DL. 2001. PAUP 4.0b: Phylogenetic Analysis Using Parsimony. Sunderland: Sinauer Associates.

Toledo, RC, Jared C. 1993. Cutaneous adaptations to water balance in amphibians. Comparative Biochemistry and Physiology, part A 105: 593-608. 
Vliet MS van de, Beebee TJC, Diekmann OE. 2012. Genetic evidence for a distinct Pelodytes lineage in southwest Portugal: implications for the use of pre-developed microsatellite markers. Conservation Genetics 13: 605-611.

Wilkinson JW, Beebee TJC, Griffiths RA. 2007. Conservation genetics of an island toad: Bufo bufo in Jersey. Herpetological Journal 17: 192-198.

Ye C, Fei L, Hu S. 1993. Rare and economic amphibians of China. Chengdu: Sichuan Publishing House of Science and Technology. [in Chinese]
Zhan AB, Fu JZ. 2011. Past and present: Phylogeography of the Bufo gargarizans species complex inferred from multi-loci allele sequence and frequency data. Molecular Phylogenetics and Evolution 61: 136-148.

Received: 10 July 2013

Revised and accepted: 25 October 2013

Published online: 5 December 2013

Editor: J. van Rooijen 


\section{APPENDICES}

\section{Appendix I}

Material studied from the collections of the Naturalis Biodiversity Center, Leiden (The Netherlands), the National Museum of Natural History, Paris (France) and the National Museum of Natural Sciences, Madrid (Spain). Coordinates latitude and longitude are in square brackets. Altitudes are in $\mathrm{m}$ above sea level (a.s.l.) and approximated with Google Earth. $\hat{\delta}=$ male and $q=$ female. Toads from localities a-c, 1-3, 5 and 13 are identified as Bufo bufo and all others as B. spinosus. For completeness sake we provide the coordinates and altitudes of localities a-e (Fig. 1) as follows: a) Audresselles [50.82134, 1.60194, 10 m.a.s.1.]. b) Autreppes [49.91492, 3.84678, 152 m.a.s.1.]. c) Sorques [48.34485, 2.77790, 65 m.a.s.1.]. d) Jublains [48.23955, -0.55190 , 140 m.a.s.l.]. e) Gizeux [47.37608, 0.26945, 88 m.a.s.l.].

Naturalis Biodiversity Center, Leiden, the Netherlands: 1) Charnwood, Colony Reservoir, Coalville, United Kingdom [52.733, -1.313, 208 m.a.s.l.] RenA.ZMA_

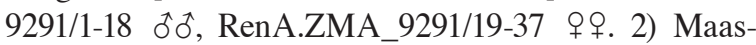
tricht [50.85, 5.69, 58 m.a.s.1.] RenA.RMNH_9598/1-3 §ô, RenA.RMNH_9598/4-5 우,RenA.RMNH_9598/6-

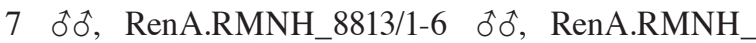
8813/7-11 우, RenA.RMNH_9308/1 $\widehat{0}$, RenA.RMNH_ 9308/2-7 우. 3) Landgoed Heuven, Rheden, [52.01, 6.03,

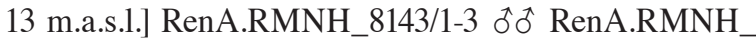
8143/4-5 우오.

Muséum national d'Histoire naturelle, Paris, France: 4a) Ariège, Lac de Bethmale [42.860, 1.085, 1065 m.a.s.1.] 1971.0337 o. 4b) Ariège, Moulis Labo CNRS [42.950, 1.083, 440 m.a.s.1.] 1971.0338 §. 5) Aube, Foret d'Orient [48.31, 4.41, 155 m.a.s.1.] 1988.5659 ठิ, 1988.5660 ô, 1988.5661 ô, 1988.5662 ô, 1988.5663 ๙ै, 1988.5664 ô, 1988.5665 ô, 1988.5666 ô, 1988.5667 đ. 6) Landes [44.25, 1.00, 64 m.a.s.1.] 1988.6699 ․ 7) Midi-Pyrénées, Bagnères de Bigorre [43.067, 0.150, 566 m.a.s.1..] 1973.0046 ‥ 8) Midi-Pyrénées, Lac de Bordères [42.861, 0.460, 1785 m.a.s.1.] 1973.0047 \%.9) Puerto de Leitariegos, Spain [42.995, -6.412, 1260 m.a.s.1.] 1994.7851 o, 1994.7852 o, 1994.7853 o, 1994.7854 o, 1994.7855 $\lesssim .10)$ Puy du Dome, Lac de la Cossière [45.67, 3.00, 776 m.a.s.1.] 1988.7763 ô. 11) Pyrénées Atlantique, Etang du plateau d'Iraty, $6,8 \mathrm{~km}$ à l'Ouest du col Bagargui [43.046, -1.074, 1067 m.a.s.l.] 1984.2291 o, 1984.2292 ô, 1984.2293 o, 1984.2294 đૈ, 1984.2295 क, 1984.2296 ㅇ, 1984.2297 ô. 12) Rio Dinha, Portugal [40.517, -8.067, 260 m.a.s.1.] 1970.1174 đิ, 1970.1175 đ.. 13) Val d'Oise, Carnelle, Lac Bleu [49.120, 2.319, 169 m.a.s.1.] 1988.7544 ô, 1988.7682 , 1988.7683 ㅇ, 1988.7685 ㅇ, 1988.7694 ㅇ, 1988.7697 ㅇ,

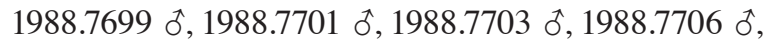
$1988.7707 \uparrow, 1988.7708$ ô, 1988.7710 q and 1988.7711 ○.

Museo Nacional de Ciencias Naturales, Madrid, Spain: 14) Laguna del Barco, Puerto Castilla, Ávila [40.23, -5.60, 1789 m.a.s.l.] 25331 ô and 25332 ․ 15) San Pedro del Valle (=Xestoso), Rebordelo / Monfero, A Coruña [43.01, -9.17, 105 m.a.s.l.] 25626 , 25627 q, 25628 ๆ, 25629 , 30480 ๙ิ, 30481 , 42155 ․ 16) Peña Gorbea, Murguía, Álava [42.96, -2.82, 1332

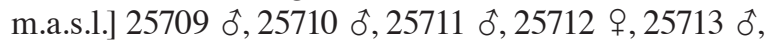

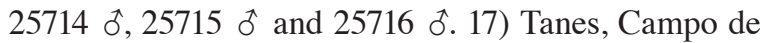
Caso, Asturias [43.18, -5.34, 517 m.a.s.1.] 25497 o,

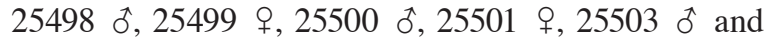
25504 ․ 18a) 13,9 km east of Facinas, Los Barrios, Cádiz [36.19, -5.49, 25 m.a.s.1.] 11132 ․ 18b) 12,9-23,3 km east of Facinas, Los Barrios, Cádiz [36.19, -5.49, 25 m.a.s.l.] 11133 \&, 11134 o, 11135 ㅇ, 11136 , 11137 ot, 11138 ๆ and 11139 ๆ. 18c) Los Barrios, Cádiz [36.19, -5.49, 25 m.a.s.l.] 11155 q and 11157 q. 18d) Tarifa-Los Barrios, Cádiz [36.19, -5.49, 25 m.a.s.l.] 11152 †, 11154 $\uparrow$ and 11156 †. 19) Alcalá de los Gazules, Cádiz [36.46, -5.72, 185 m.a.s.1.] 11141 \&, 11142 \%, 11143 , 11144 , 11145 을 11147 ․ 20a) Tarifa, Cádiz [36.01, -5.60, 50 m.a.s.l.] 11151 . 20b) Facinas, Tarifa, Cádiz [36.02, -5.60, 50 m.a.s.1.] 25085 ‥ 21a) Barcenilla, Ruente, Cantabria [43.26, -4.27, 222 m.a.s.1.] 16824 ․ 21b) Ucieda, Ruente, Cantabria [43.26, -4.27, 198 m.a.s.1.] 25196 ơ. 21c) Río Saja (Ucieda), Ruente, Cantabria [43.26, -4.27, 184 m.a.s.1.] 41483 o, 41484 o and 41485 . 22a) Arroyo de la Fuenfría, Puerto de La Fuenfría, Madrid [40.78, -4.05, 1794 m.a.s.l.] 2800 ô and 2801 oे. 22b) Las Dehesas, Cercedilla, Madrid [40.78, -4.05, 1794 m.a.s.1.] 25517 q, 25518 ○, 25519 ㅇ, 25520 क,

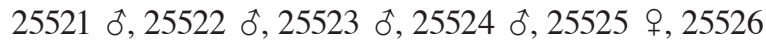

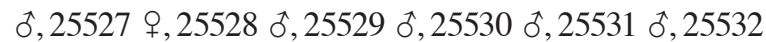

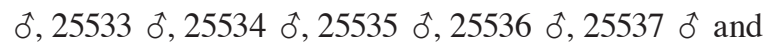
25538 ô. 22c) Puerto de La Fuenfría, Madrid [40.78, -4.05, 1794 m.a.s.1.] 25539 ค. 23a) Cinco Lagunas, Sierra de Gredos, Ávila [40.25, -5.27, 2111 m.a.s.1.] 2729 ․ 23b) Circo de Gredos, Ávila [40.25, -5.27, 1945

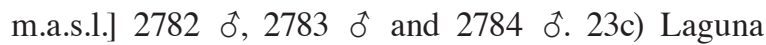
Grande de Gredos, Ávila [40.25, -5.27, 1945 m.a.s.1.] 1852 \%, $2773 q$ and 16825 $+.23 \mathrm{~d}$ ) Prado de las Pozas, Hoyos del Espino, Ávila [40.25, -5.27, 1931 m.a.s.1.] 30482 đิ, 30483 ô and 30484 ô. 24a) Los Baños de 
Benasque, Huesca [42.60, 0.52, 1150 m.a.s.1.] 2740 \%, 2742 \%, 2743 \&, 2744 o and 2745 \%. 24b) Benasque, Huesca [42.60, 0.52, 1150 m.a.s.l.] 25130 ๆ. 25) Ibón de Piedrafita, Huesca [42.70, -0.36, 1618 m.a.s.l.] 9528 , 9529 +, 9530 +, 9532 +, 9533 +, 9534 +, 9535 +, 9536 đ, 9537 ô, 9538 o and 25141 ‥ 26) El Pueyo de Jaca, Panticosa, Huesca [42.72, -0.28, 1097 m.a.s.l.] 9926 o, 9927 ․, 9928 o, 9929 ô, 9930 ô, 9931 ô, 9932 ô, 9933 \& and 9934 o.27) Selva de Oza, Hecho, Huesca [42.74, -0.75, 823 m.a.s.l.] $9941+$ and 9948 o. 28) Monasterio de Valvanera, Anguiano, La Rioja [42.23, -2.87, 995 m.a.s.l.] 25690 \%, 25691 \%, 25692 +, 30605 \&, 30606

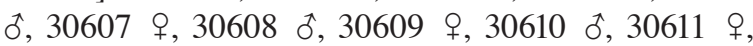
30612 o, 30613 \%, 30614 \%, 30615 and 30616 . 29) Nacimiento del Río Oja, Sierra de la Demanda, Ezcaray, La Rioja [42.33, -3.01, 1430 m.a.s.1.] 25695 o. 30) Puerto de Vegarada, Valdelugueros, León [43.03, -5.48, 1572 m.a.s.l.] 13003 ô, 13004 ㅇ, 13005 ㅇ, 13006 ô, 13007

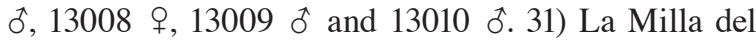
Río, Carrizo, León [42.58, -5.83, 875 m.a.s.1.] 13174 ऽ. 32) La Uña, Acebedo, León [43.03, -5.13, 1189 m.a.s.1.] 25367 ๙, 25368 ㅇ, 25369 ㅇ, 25370 ㅇ, 25371ㅇ, 25373 우 and 25375 9.33 a) A Pobra de Burón, Fonsagrada, Lugo [43.13, -7.06, 907 m.a.s.1.] 25636 +, 25637 \&, 25638 q, 25639 , 25640 \%, $25641 \%, 25642$ \%, 25643 \&, 25644 , 25645 , 25647 , 25648 ๙, 25649 , 25651 , 25652 +, 25653 q and 25654 $.33 \mathrm{~b})$ Pedrafitelas, Fonsagrada, Lugo [43.13, -7.06, 907 m.a.s.1.] 25646 \%, $26205 \%$ and 42154 \%. 34) Frigiliana, Málaga [36.79, -3.90, 324 m.a.s.1.] 25110 \%, 25111 \%, 25112 o, 25114 o,

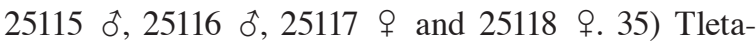
Ketama, Morocco [34.88, -4.62, 1300 m.a.s.1.] 645 q. 36) Imlil, Morocco [31.13, -7.92, 1911 m.a.s.1.] 2749 q, $2750 \%$ and 2751 o. 37) Río Urtxurria, Bosque de Irati, Ochagavia, Navarra [42.91, -1.09, 760 m.a.s.1.] 2760 ठ,

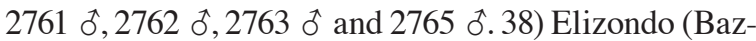
tán), Navarra [43.14, -1.52, 202 m.a.s.1.] 25580 , 25584 +, 25589 q and 25590 ๆ. 39) Sierra do Gerês, Pitoes, Portugal [41.73, -8.16, 382 m.a.s.1.] 25075 9. 40a) Porto Covo - S. do Cacem, Portugal [several localities] 24584

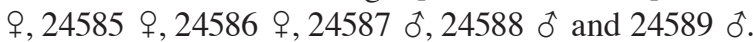
40b) Porto Covo, Portugal [37.85, -8.79, 25 m.a.s.1.] 16612 o. 40c) Castillo de la Isla do Pessegueiro, Porto Covo, Portugal [37.83, -8.80, 0 m.a.s.1.] 24582 ㅇ.

\section{Appendix II}

Restriction profile of the Bufo cytochrome b sequence after treatment with the endonuclease BcuI. Bufo bufo has two recognition sites for this enzyme whereas

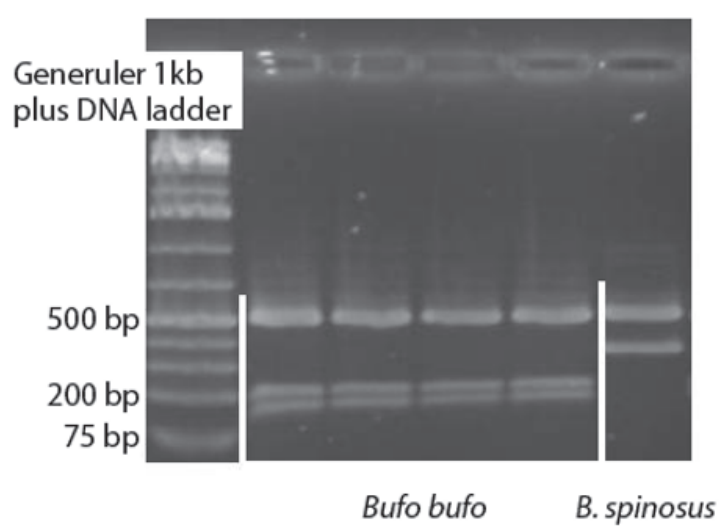

B. spinosus has one, resulting in three and two size fragments, respectively.

\section{Appendix III}

Bivariate plot of untransformed measurements on the length and width of the metatarsal tubercle in male (top) and female toads (bottom), taken on live material in the field, Northern France (left) and in museum collections from across Western Europe (right). Solid dots represent Bufo bufo and open dots represent B. spinosus. Data are summarized by convex polygons. Note the wide spread in the preserved material that, however, does not seem to compromise species identification.

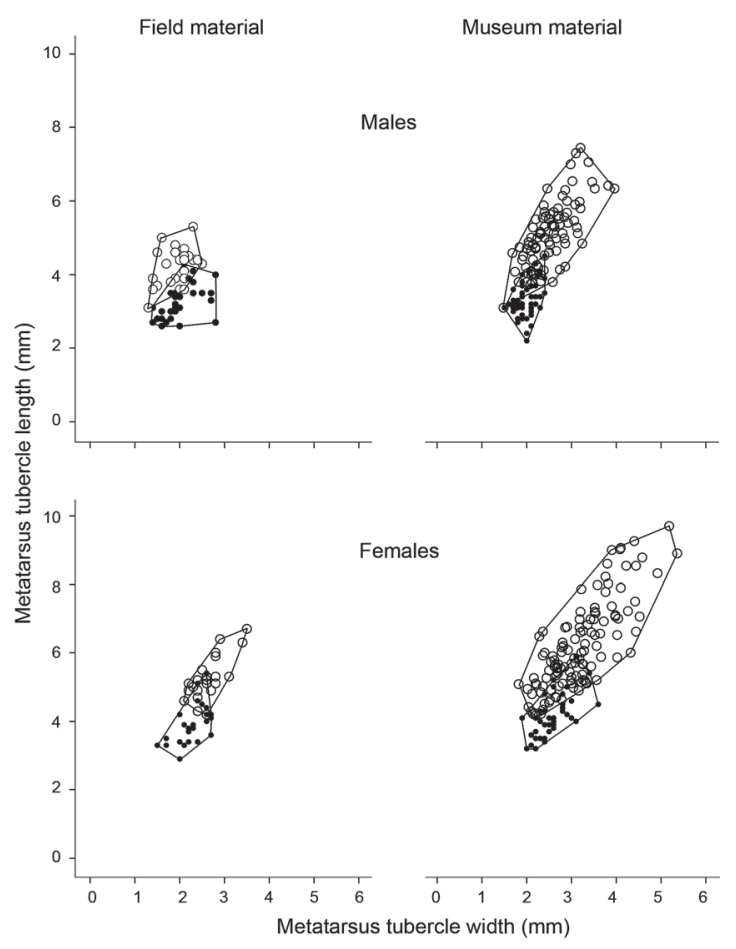




\section{Appendix IV}

Summary of inter- and intra-specific morphological variation (average, standard deviation (SD), 95\% confidence interval of the average (CI95 low and high) and range (min-max)) in Bufo bufo and B. spinosus populations for which sample size $\mathrm{N} \geq 5$. Top panel males, middle panel - females, bottom panel - cheek spines for males and females (preserved material only). For population localities see Fig. 1 (a-e, live material) and Appendix I (1-40, preserved material). Toads from localities a-c, 1-3, 5 and 13 are identified as Bufo bufo and all others as B. spinosus.

Males

\begin{tabular}{|c|c|c|c|c|c|c|c|c|}
\hline Character & Population & $\mathrm{N}$ & Average & SD & CI95low & CI95high & Min & Max \\
\hline \multicolumn{9}{|c|}{ Snout Urostyle length (mm) } \\
\hline & $\mathrm{a}$ & 11 & 60.7 & 4.41 & 57.77 & 63.69 & 55.0 & 71.0 \\
\hline & $\mathrm{b}$ & 15 & 61.8 & 4.02 & 59.57 & 64.03 & 57.0 & 70.0 \\
\hline & $\mathrm{c}$ & 8 & 68.3 & 5.85 & 63.36 & 73.14 & 56.0 & 76.0 \\
\hline & $\mathrm{d}$ & 13 & 63.6 & 4.23 & 61.06 & 66.17 & 58.0 & 72.0 \\
\hline & $\mathrm{e}$ & 11 & 70.5 & 4.03 & 67.75 & 73.17 & 65.0 & 77.5 \\
\hline & 1 & 18 & 53.5 & 4.11 & 51.46 & 55.54 & 44.0 & 63.0 \\
\hline & 2 & 12 & 62.0 & 3.16 & 59.99 & 64.01 & 57.0 & 66.0 \\
\hline & 5 & 9 & 57.8 & 2.58 & 55.85 & 59.82 & 54.0 & 61.0 \\
\hline & 9 & 5 & 78.9 & 3.95 & 74.01 & 83.83 & 74.0 & 84.0 \\
\hline & 11 & 5 & 69.0 & 8.03 & 59.05 & 78.99 & 60.0 & 76.0 \\
\hline & 13 & 8 & 59.8 & 2.88 & 57.40 & 62.22 & 57.0 & 64.0 \\
\hline & 16 & 7 & 59.6 & 5.26 & 54.71 & 64.43 & 54.0 & 70.0 \\
\hline & 22 & 20 & 70.5 & 3.99 & 68.63 & 72.37 & 65.0 & 78.0 \\
\hline & 23 & 6 & 79.3 & 5.32 & 73.75 & 84.91 & 73.0 & 89.0 \\
\hline & 26 & 6 & 84.2 & 10.59 & 73.05 & 95.28 & 70.0 & 97.0 \\
\hline & 30 & 5 & 66.4 & 5.13 & 60.03 & 72.77 & 60.0 & 73.0 \\
\hline & 37 & 5 & 60.4 & 2.88 & 56.82 & 63.98 & 57.0 & 64.0 \\
\hline \multicolumn{9}{|c|}{ Parotoid angle (degrees) } \\
\hline & $\mathrm{a}$ & 11 & 80.3 & 4.25 & 77.42 & 83.13 & 73.5 & 86.0 \\
\hline & $\mathrm{b}$ & 15 & 78.5 & 10.01 & 72.99 & 84.08 & 54.0 & 103.0 \\
\hline & $\mathrm{c}$ & 8 & 75.0 & 10.00 & 66.64 & 83.36 & 61.0 & 92.5 \\
\hline & $\mathrm{d}$ & 13 & 65.2 & 10.59 & 58.83 & 71.63 & 40.0 & 87.0 \\
\hline & $\mathrm{e}$ & 11 & 51.0 & 10.04 & 44.30 & 57.79 & 37.5 & 68.5 \\
\hline & 1 & 18 & 72.8 & 6.36 & 69.62 & 75.94 & 61.0 & 83.0 \\
\hline & 2 & 12 & 75.3 & 7.78 & 70.31 & 80.20 & 66.0 & 92.0 \\
\hline & 5 & 9 & 74.2 & 6.08 & 69.55 & 78.89 & 63.0 & 85.0 \\
\hline & 9 & 5 & 59.6 & 4.22 & 54.36 & 64.84 & 54.0 & 65.0 \\
\hline & 11 & 5 & 63.5 & 10.09 & 50.98 & 76.03 & 51.0 & 76.0 \\
\hline & 13 & 8 & 77.1 & 8.65 & 69.90 & 84.35 & 64.5 & 89.5 \\
\hline & 16 & 7 & 63.7 & 6.40 & 57.80 & 69.63 & 55.0 & 70.5 \\
\hline & 22 & 20 & 61.9 & 7.40 & 58.39 & 65.31 & 43.5 & 76.0 \\
\hline & 23 & 6 & 43.7 & 9.02 & 34.20 & 53.13 & 29.0 & 56.5 \\
\hline & 26 & 6 & 53.8 & 7.99 & 45.45 & 62.22 & 40.0 & 61.0 \\
\hline & 30 & 5 & 60.5 & 5.71 & 53.41 & 67.59 & 54.5 & 66.5 \\
\hline & 37 & 5 & 70.0 & 9.69 & 57.97 & 82.03 & 62.5 & 85.0 \\
\hline \multicolumn{9}{|c|}{ Parotoid divergence (Pda $(\mathrm{mm}) / \mathrm{Pdp}(\mathrm{mm}))$} \\
\hline & a & 11 & 0.85 & 0.048 & 0.820 & 0.884 & 0.77 & 0.92 \\
\hline & $\mathrm{b}$ & 15 & 0.88 & 0.114 & 0.814 & 0.940 & 0.68 & 1.20 \\
\hline & $\mathrm{c}$ & 8 & 0.83 & 0.094 & 0.755 & 0.911 & 0.74 & 1.02 \\
\hline & $\mathrm{d}$ & 13 & 0.74 & 0.100 & 0.682 & 0.803 & 0.59 & 1.00 \\
\hline & $\mathrm{e}$ & 11 & 0.69 & 0.072 & 0.644 & 0.740 & 0.58 & 0.83 \\
\hline & 1 & 18 & 0.83 & 0.066 & 0.801 & 0.867 & 0.69 & 0.93 \\
\hline & 2 & 12 & 0.90 & 0.060 & 0.858 & 0.934 & 0.83 & 1.01 \\
\hline
\end{tabular}




\begin{tabular}{|c|c|c|c|c|c|c|c|}
\hline 5 & 9 & 0.83 & 0.037 & 0.798 & 0.856 & 0.78 & 0.89 \\
\hline 9 & 5 & 0.76 & 0.039 & 0.711 & 0.809 & 0.70 & 0.80 \\
\hline 11 & 5 & 0.82 & 0.022 & 0.792 & 0.847 & 0.80 & 0.85 \\
\hline 13 & 8 & 0.89 & 0.059 & 0.837 & 0.936 & 0.80 & 0.96 \\
\hline 16 & 7 & 0.82 & 0.047 & 0.773 & 0.859 & 0.75 & 0.86 \\
\hline 22 & 20 & 0.75 & 0.067 & 0.720 & 0.783 & 0.60 & 0.89 \\
\hline 23 & 6 & 0.65 & 0.042 & 0.609 & 0.697 & 0.60 & 0.72 \\
\hline 26 & 6 & 0.68 & 0.076 & 0.598 & 0.759 & 0.59 & 0.76 \\
\hline 30 & 5 & 0.77 & 0.055 & 0.701 & 0.837 & 0.70 & 0.84 \\
\hline 37 & 5 & 0.80 & 0.054 & 0.738 & 0.872 & 0.74 & 0.88 \\
\hline \multicolumn{8}{|c|}{ Metatarsal tubercle size (MTl (mm) / SUl (mm)) } \\
\hline a & 11 & 0.053 & 0.0067 & 0.0489 & 0.0579 & 0.044 & 0.067 \\
\hline $\mathrm{b}$ & 15 & 0.050 & 0.0074 & 0.0455 & 0.0538 & 0.039 & 0.068 \\
\hline $\mathrm{c}$ & 8 & 0.056 & 0.0032 & 0.0532 & 0.0585 & 0.050 & 0.060 \\
\hline $\mathrm{d}$ & 13 & 0.065 & 0.0073 & 0.0604 & 0.0693 & 0.051 & 0.075 \\
\hline $\mathrm{e}$ & 11 & 0.062 & 0.0069 & 0.0571 & 0.0663 & 0.053 & 0.075 \\
\hline 1 & 18 & 0.057 & 0.0068 & 0.0538 & 0.0605 & 0.046 & 0.069 \\
\hline 2 & 12 & 0.058 & 0.0072 & 0.0538 & 0.0629 & 0.048 & 0.070 \\
\hline 5 & 9 & 0.058 & 0.0060 & 0.0534 & 0.0626 & 0.051 & 0.070 \\
\hline 9 & 5 & 0.064 & 0.0061 & 0.0565 & 0.0716 & 0.060 & 0.074 \\
\hline 11 & 5 & 0.075 & 0.0144 & 0.0576 & 0.0933 & 0.064 & 0.100 \\
\hline 13 & 8 & 0.054 & 0.0055 & 0.0490 & 0.0583 & 0.049 & 0.065 \\
\hline 16 & 7 & 0.071 & 0.0080 & 0.0637 & 0.0785 & 0.056 & 0.080 \\
\hline 22 & 20 & 0.072 & 0.0117 & 0.0665 & 0.0775 & 0.054 & 0.095 \\
\hline 23 & 6 & 0.070 & 0.0049 & 0.0653 & 0.0755 & 0.062 & 0.077 \\
\hline 26 & 6 & 0.068 & 0.0026 & 0.0654 & 0.0709 & 0.065 & 0.072 \\
\hline 30 & 5 & 0.070 & 0.0056 & 0.0631 & 0.0770 & 0.062 & 0.076 \\
\hline 37 & 5 & 0.062 & 0.0059 & 0.0549 & 0.0695 & 0.054 & 0.070 \\
\hline \multicolumn{8}{|c|}{ Metatarsal tubercle shape (MTw (mm) / (MTl (mm)) } \\
\hline a & 11 & 0.67 & 0.160 & 0.560 & 0.775 & 0.51 & 1.04 \\
\hline $\mathrm{b}$ & 15 & 0.59 & 0.076 & 0.545 & 0.629 & 0.45 & 0.77 \\
\hline $\mathrm{c}$ & 8 & 0.59 & 0.069 & 0.536 & 0.651 & 0.49 & 0.70 \\
\hline $\mathrm{d}$ & 13 & 0.44 & 0.092 & 0.388 & 0.498 & 0.32 & 0.58 \\
\hline $\mathrm{e}$ & 11 & 0.48 & 0.048 & 0.444 & 0.508 & 0.40 & 0.55 \\
\hline 1 & 18 & 0.67 & 0.103 & 0.617 & 0.720 & 0.50 & 0.91 \\
\hline 2 & 12 & 0.60 & 0.063 & 0.564 & 0.644 & 0.51 & 0.69 \\
\hline 5 & 9 & 0.52 & 0.031 & 0.496 & 0.544 & 0.47 & 0.57 \\
\hline 9 & 5 & 0.46 & 0.056 & 0.389 & 0.529 & 0.40 & 0.54 \\
\hline 11 & 5 & 0.47 & 0.052 & 0.406 & 0.535 & 0.42 & 0.53 \\
\hline 13 & 8 & 0.61 & 0.070 & 0.551 & 0.669 & 0.51 & 0.71 \\
\hline 16 & 7 & 0.46 & 0.051 & 0.414 & 0.509 & 0.39 & 0.55 \\
\hline 22 & 20 & 0.49 & 0.068 & 0.461 & 0.525 & 0.39 & 0.68 \\
\hline 23 & 6 & 0.52 & 0.097 & 0.416 & 0.619 & 0.41 & 0.67 \\
\hline 26 & 6 & 0.50 & 0.077 & 0.423 & 0.585 & 0.42 & 0.62 \\
\hline 30 & 5 & 0.47 & 0.044 & 0.419 & 0.527 & 0.43 & 0.53 \\
\hline 37 & 5 & 0.54 & 0.049 & 0.479 & 0.601 & 0.48 & 0.61 \\
\hline
\end{tabular}


Females

\begin{tabular}{|c|c|c|c|c|c|c|c|c|}
\hline Character & Population & $\mathrm{N}$ & Average & SD & CI95low & CI95high & Min & Max \\
\hline \multicolumn{9}{|c|}{ Snout Urostyle length (mm) } \\
\hline & $\mathrm{a}$ & 11 & 73.4 & 4.39 & 70.42 & 76.31 & 67.0 & 79.0 \\
\hline & $\mathrm{b}$ & 10 & 71.8 & 3.46 & 69.33 & 74.27 & 66.0 & 78.0 \\
\hline & $\mathrm{d}$ & 16 & 83.8 & 8.75 & 79.15 & 88.48 & 67.0 & 98.0 \\
\hline & $\mathrm{e}$ & 7 & 80.4 & 6.86 & 74.01 & 86.70 & 73.0 & 89.5 \\
\hline & 1 & 19 & 65.4 & 7.16 & 61.97 & 68.87 & 52.0 & 78.0 \\
\hline & 2 & 13 & 75.0 & 4.88 & 72.05 & 77.95 & 69.0 & 83.0 \\
\hline & 13 & 6 & 73.5 & 5.72 & 67.51 & 79.52 & 67.0 & 80.0 \\
\hline & 15 & 6 & 76.3 & 8.04 & 67.89 & 84.77 & 65.0 & 87.0 \\
\hline & 18 & 11 & 102.4 & 25.45 & 85.26 & 119.46 & 69.0 & 150.0 \\
\hline & 19 & 6 & 101.7 & 11.76 & 89.33 & 114.01 & 89.0 & 117.0 \\
\hline & 22 & 5 & 93.6 & 13.61 & 76.70 & 110.50 & 79.0 & 114.0 \\
\hline & 24 & 5 & 91.4 & 16.07 & 71.44 & 111.36 & 80.0 & 119.0 \\
\hline & 25 & 8 & 102.8 & 7.03 & 96.88 & 108.62 & 95.0 & 115.0 \\
\hline & 28 & 11 & 78.9 & 11.78 & 71.00 & 86.82 & 67.0 & 99.0 \\
\hline & 32 & 5 & 83.0 & 3.16 & 79.07 & 86.93 & 80.0 & 88.0 \\
\hline & 33 & 19 & 84.2 & 6.82 & 80.92 & 87.50 & 74.0 & 96.0 \\
\hline \multicolumn{9}{|c|}{ Parotoid angle (degrees) } \\
\hline & $\mathrm{a}$ & 11 & 75.7 & 8.32 & 70.14 & 81.32 & 63.0 & 87.0 \\
\hline & $\mathrm{b}$ & 10 & 78.1 & 4.46 & 74.91 & 81.29 & 71.0 & 86.5 \\
\hline & $\mathrm{d}$ & 16 & 62.7 & 13.78 & 55.38 & 70.06 & 31.5 & 81.0 \\
\hline & $\mathrm{e}$ & 7 & 51.4 & 13.22 & 39.13 & 63.59 & 30.0 & 66.0 \\
\hline & 1 & 19 & 74.4 & 10.31 & 69.43 & 79.36 & 52.5 & 92.0 \\
\hline & 2 & 13 & 74.5 & 9.07 & 68.98 & 79.94 & 55.0 & 91.0 \\
\hline & 13 & 6 & 75.0 & 8.03 & 66.58 & 83.42 & 63.0 & 85.0 \\
\hline & 15 & 6 & 68.7 & 11.95 & 56.12 & 81.21 & 50.5 & 83.0 \\
\hline & 18 & 11 & 49.9 & 13.16 & 41.02 & 58.71 & 30.5 & 65.5 \\
\hline & 19 & 6 & 47.4 & 5.48 & 41.67 & 53.17 & 40.5 & 57.0 \\
\hline & 22 & 5 & 46.2 & 18.23 & 23.57 & 68.83 & 20.5 & 69.5 \\
\hline & 24 & 5 & 61.0 & 14.71 & 42.73 & 79.27 & 36.0 & 75.0 \\
\hline & 25 & 8 & 50.4 & 6.51 & 45.00 & 55.88 & 41.0 & 59.5 \\
\hline & 28 & 11 & 54.1 & 14.17 & 44.57 & 63.61 & 23.5 & 82.5 \\
\hline & 32 & 5 & 54.3 & 8.03 & 44.33 & 64.27 & 41.5 & 62.0 \\
\hline & 33 & 19 & 63.7 & 8.17 & 59.80 & 67.67 & 45.0 & 75.5 \\
\hline \multicolumn{9}{|c|}{ Parotoid divergence (Pda (mm)/Pdp (mm)) } \\
\hline & $\mathrm{a}$ & 11 & 0.84 & 0.089 & 0.784 & 0.904 & 0.71 & 0.97 \\
\hline & $\mathrm{b}$ & 10 & 0.86 & 0.038 & 0.833 & 0.888 & 0.78 & 0.92 \\
\hline & $\mathrm{d}$ & 16 & 0.73 & 0.089 & 0.686 & 0.781 & 0.56 & 0.90 \\
\hline & $\mathrm{e}$ & 7 & 0.67 & 0.070 & 0.608 & 0.737 & 0.54 & 0.76 \\
\hline & 1 & 19 & 0.88 & 0.071 & 0.843 & 0.911 & 0.76 & 0.99 \\
\hline & 2 & 13 & 0.86 & 0.064 & 0.819 & 0.897 & 0.73 & 0.96 \\
\hline & 13 & 6 & 0.86 & 0.069 & 0.792 & 0.936 & 0.78 & 0.94 \\
\hline & 15 & 6 & 0.84 & 0.063 & 0.778 & 0.911 & 0.73 & 0.90 \\
\hline & 18 & 11 & 0.68 & 0.098 & 0.615 & 0.746 & 0.51 & 0.80 \\
\hline & 19 & 6 & 0.68 & 0.053 & 0.624 & 0.735 & 0.58 & 0.73 \\
\hline & 22 & 5 & 0.63 & 0.107 & 0.501 & 0.767 & 0.50 & 0.77 \\
\hline & 24 & 5 & 0.72 & 0.041 & 0.670 & 0.771 & 0.67 & 0.77 \\
\hline & 25 & 8 & 0.71 & 0.050 & 0.670 & 0.754 & 0.62 & 0.78 \\
\hline & 28 & 11 & 0.74 & 0.074 & 0.687 & 0.787 & 0.60 & 0.85 \\
\hline & 32 & 5 & 0.74 & 0.052 & 0.674 & 0.802 & 0.68 & 0.81 \\
\hline & 33 & 19 & 0.81 & 0.079 & 0.774 & 0.850 & 0.69 & 0.95 \\
\hline
\end{tabular}




\begin{tabular}{|c|c|c|c|c|c|c|c|}
\hline \multicolumn{8}{|c|}{ Metatarsal tubercle size (MTl (mm) / SUl (mm)) } \\
\hline a & 11 & 0.058 & 0.0045 & 0.0546 & 0.0606 & 0.051 & 0.068 \\
\hline $\mathrm{b}$ & 10 & 0.048 & 0.0036 & 0.0451 & 0.0502 & 0.040 & 0.053 \\
\hline $\mathrm{d}$ & 16 & 0.065 & 0.0066 & 0.0610 & 0.0681 & 0.053 & 0.076 \\
\hline e & 7 & 0.063 & 0.0037 & 0.0596 & 0.0665 & 0.058 & 0.067 \\
\hline 1 & 19 & 0.062 & 0.0075 & 0.0586 & 0.0658 & 0.052 & 0.081 \\
\hline 2 & 13 & 0.054 & 0.0061 & 0.0504 & 0.0577 & 0.044 & 0.069 \\
\hline 13 & 6 & 0.055 & 0.0044 & 0.0503 & 0.0595 & 0.051 & 0.061 \\
\hline 15 & 6 & 0.064 & 0.0076 & 0.0565 & 0.0724 & 0.058 & 0.078 \\
\hline 18 & 11 & 0.062 & 0.0053 & 0.0582 & 0.0653 & 0.051 & 0.069 \\
\hline 19 & 6 & 0.064 & 0.0077 & 0.0560 & 0.0721 & 0.054 & 0.075 \\
\hline 22 & 5 & 0.067 & 0.0035 & 0.0624 & 0.0711 & 0.061 & 0.071 \\
\hline 24 & 5 & 0.073 & 0.0078 & 0.0632 & 0.0826 & 0.068 & 0.087 \\
\hline 25 & 8 & 0.071 & 0.0091 & 0.0636 & 0.0788 & 0.060 & 0.089 \\
\hline 28 & 11 & 0.074 & 0.0044 & 0.0711 & 0.0770 & 0.070 & 0.084 \\
\hline 32 & 5 & 0.062 & 0.0059 & 0.0551 & 0.0697 & 0.056 & 0.068 \\
\hline 33 & 19 & 0.065 & 0.0076 & 0.0616 & 0.0690 & 0.052 & 0.083 \\
\hline \multicolumn{8}{|c|}{ Metatarsal tubercle shape (MTw (mm) / (MTl (mm)) } \\
\hline a & 11 & 0.58 & 0.082 & 0.526 & 0.637 & 0.47 & 0.75 \\
\hline $\mathrm{b}$ & 10 & 0.59 & 0.084 & 0.532 & 0.652 & 0.45 & 0.71 \\
\hline $\mathrm{d}$ & 16 & 0.51 & 0.050 & 0.488 & 0.541 & 0.45 & 0.62 \\
\hline e & 7 & 0.47 & 0.029 & 0.445 & 0.499 & 0.43 & 0.51 \\
\hline 1 & 19 & 0.65 & 0.059 & 0.621 & 0.678 & 0.50 & 0.78 \\
\hline 2 & 13 & 0.63 & 0.077 & 0.587 & 0.680 & 0.50 & 0.80 \\
\hline 13 & 6 & 0.58 & 0.073 & 0.498 & 0.652 & 0.46 & 0.66 \\
\hline 15 & 6 & 0.50 & 0.084 & 0.408 & 0.585 & 0.36 & 0.61 \\
\hline 18 & 11 & 0.56 & 0.043 & 0.531 & 0.589 & 0.51 & 0.64 \\
\hline 19 & 6 & 0.54 & 0.051 & 0.485 & 0.593 & 0.48 & 0.63 \\
\hline 22 & 5 & 0.49 & 0.056 & 0.420 & 0.559 & 0.40 & 0.54 \\
\hline 24 & 5 & 0.48 & 0.086 & 0.373 & 0.586 & 0.35 & 0.59 \\
\hline 25 & 8 & 0.52 & 0.096 & 0.440 & 0.600 & 0.40 & 0.67 \\
\hline 28 & 11 & 0.49 & 0.065 & 0.446 & 0.533 & 0.41 & 0.60 \\
\hline 32 & 5 & 0.61 & 0.072 & 0.525 & 0.703 & 0.54 & 0.72 \\
\hline 33 & 19 & 0.53 & 0.076 & 0.494 & 0.568 & 0.44 & 0.68 \\
\hline
\end{tabular}

Cheek spine scores

\begin{tabular}{llrl}
\hline Sex & Population & $\mathrm{N}$ & Average \\
\hline Males & 1 & 18 & 1.00 \\
& 2 & 12 & 2.08 \\
3 & 3 & 1.67 \\
5 & 9 & 1.89 \\
9 & 5 & 3.00 \\
& 11 & 5 & 3.00 \\
13 & 8 & 1.38 \\
16 & 7 & 1.43 \\
22 & 20 & 2.55 \\
& 23 & 6 & 2.33 \\
& 26 & 5 & 3.20 \\
30 & 5 & 2.00 \\
37 & 5 & 2.00 \\
\hline
\end{tabular}

\begin{tabular}{llrl}
\hline Sex & Population & $\mathrm{N}$ & Average \\
\hline Females & 1 & 19 & 1.00 \\
& 2 & 13 & 2.23 \\
3 & 2 & 2.00 \\
& 13 & 6 & 1.83 \\
15 & 6 & 4.17 \\
18 & 11 & 3.73 \\
19 & 6 & 4.17 \\
& 22 & 5 & 4.00 \\
24 & 5 & 3.20 \\
& 25 & 6 & 3.67 \\
& 28 & 11 & 3.45 \\
& 32 & 5 & 2.40 \\
& 33 & 19 & 3.89 \\
\hline
\end{tabular}




\section{Appendix V}

Schematic drawings to illustrate variation in head shape and parotoid position and shape of Bufo toads. Parotoids are in grey. Top row are males and bottom row are females. From left to right toads originate from a) Audresselles, b) Autreppes, c) Sorques, d) Jublains and e) Gizeux. Localities a-c have B. bufo, d and e have B. spinosus. The drawing is purported to illustrate difficulties in measuring 'parotoid divergence' $(\mathrm{Pd})$ because parotoid length may be asym- metric (e.g., male from Sorques, female from Autreppes) or parotoid start and end may be difficult to determine due to interaction with dorsal warts (e.g., male and female from Sorques). Occasionally parotoids may be curved or oblique (illustrated in Arnold et al. 1978: 65 and Muratet 2008: 181 female, 187 Fig. $5 b)$ which makes it difficult to measure 'parotoid angle' $(\mathrm{Pa})$. Also note the spines at the cheek in the female from Gizeux.

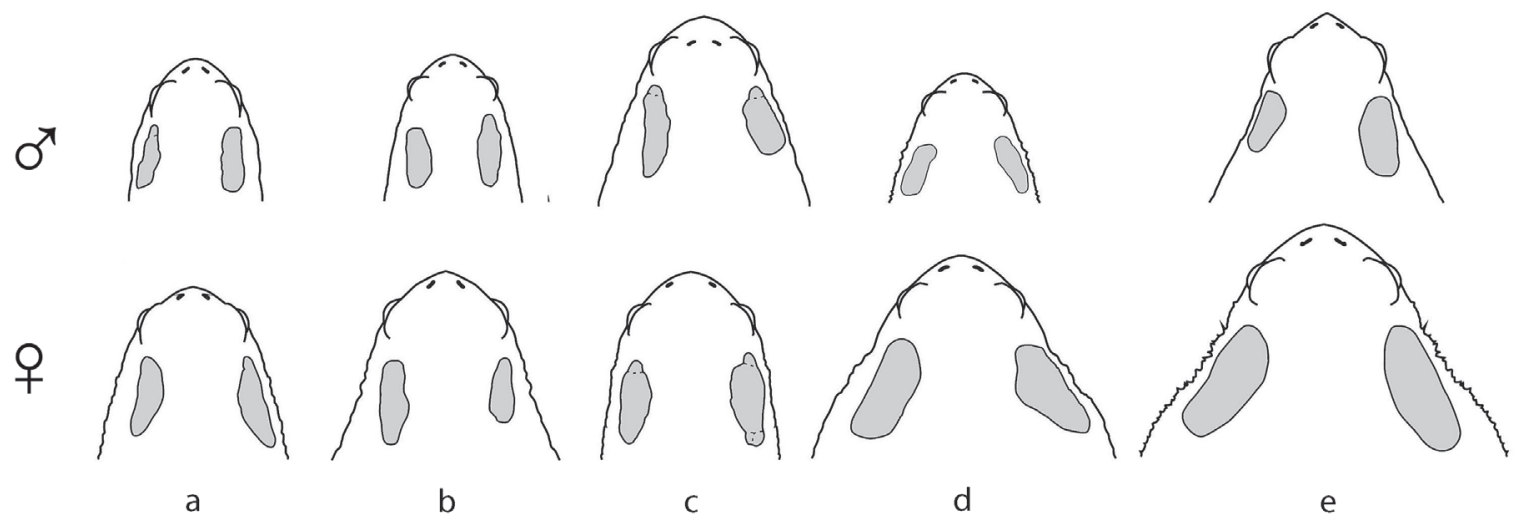

\section{Appendix VI}

The degree to which Bufo bufo and B. spinosus skins have smooth versus spined warts, as recorded by De Lange (1973: Fig. 2). Categories are 'smooth' (De Lange's classes $1-3$ in which warts are smooth, without keratinized spines), 'slightly spined' (De Lange's class 4 - with keratinized pigmented spine tops) and 'heavily spined' (De Lange's classes 5 and 6 - with fully kerati- nized single or double spines). Toads from the De Lange's regions I and II are interpreted as Bufo bufo (the north of France and northwards) and those from region III as B. spinosus (the south of France and southwards). Inspection of the collection of the Naturalis Biodiversity Center identified six specimens from Italy also in region III - that were excluded from the data set.

\begin{tabular}{lllll}
\hline Species & \multicolumn{2}{c}{ Bufo bufo } & \multicolumn{2}{l}{ Bufo spinosus } \\
\hline Sex & Males & Females & Males & Females \\
\hline Skin wart structure & & & & \\
$\quad$ Smooth & 37 & 50 & 3 & 1 \\
Slightly spined & 17 & 70 & 1 & 2 \\
Heavily spined & 1 & 15 & 3 & 9 \\
\hline
\end{tabular}




\section{Appendix VII}

The warts on the cheek are often the biggest ones on a toad's body and frequently furnished with keratinized spines, such as here shown in six adult specimens of Bufo spinosus. All toads are females, except for MNCN 25526 and 25522 which are males. Categories discerned in the character 'cheek spines' in lateral view are: 1 - absent (MNCN 25526), 2 - slight (MNCN 30481), 3 - medium (MNCN 25522), 4 - strong (MNCN 11132) and 5 - very strong (MNCN 1852). Photo 6 illustrates an extreme case of category 5 in dorsal view (MNCN 25647).
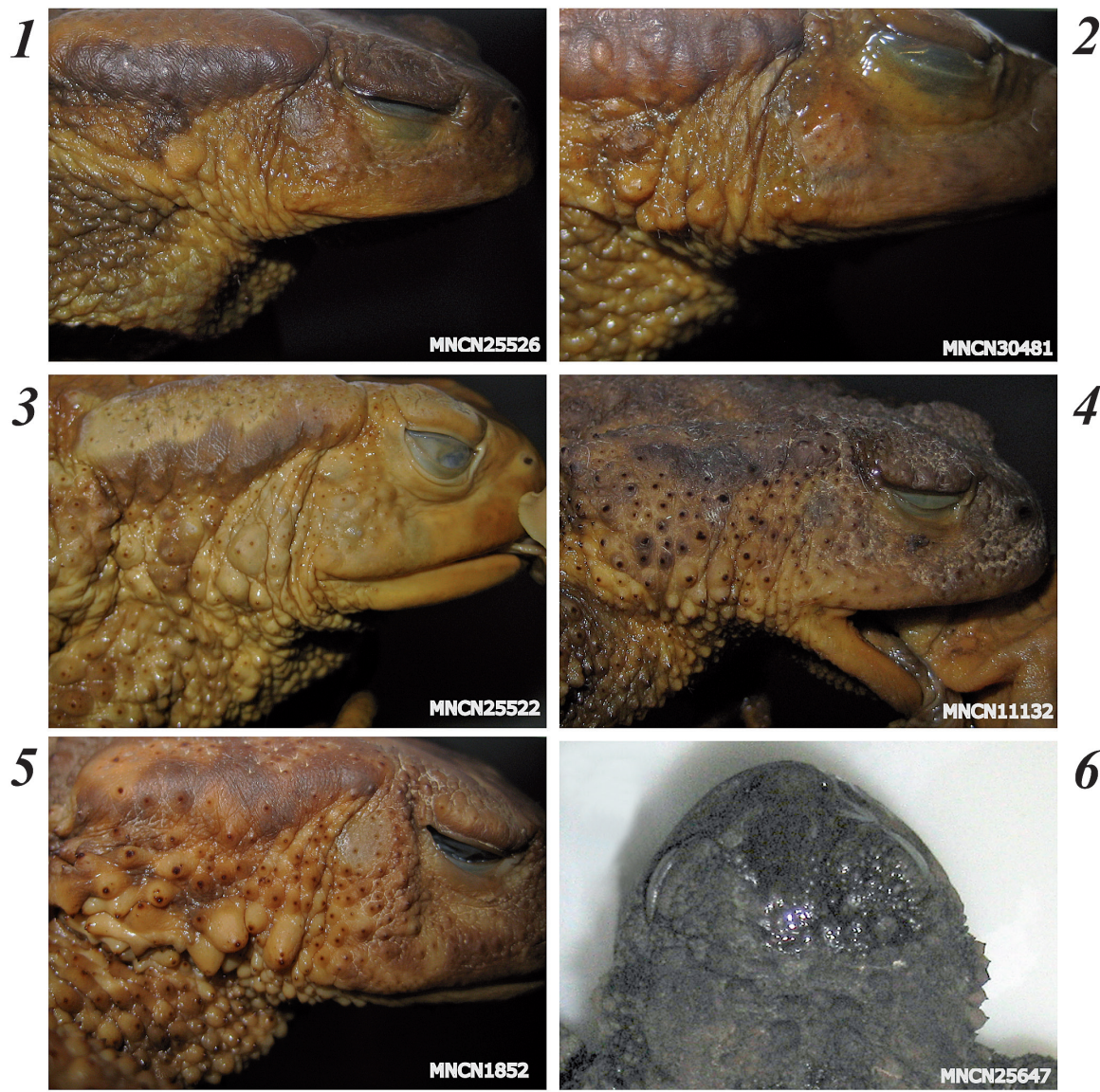

\section{Appendix VIII}

Distribution data of species in the Bufo bufo species group after Arntzen et al. (2013). Documented localities of Bufo species in Europe and North Africa, with Bufo spinosus in red, $B$. bufo in blue, B. verrucosissimus in brown and $B$. eichwaldi in green. Data sources are: Kutrup et al. (2006) open round symbols in Italy and Turkey, Recuero et al. (2012) solid round symbols, García-Porta et al. (2012) square symbols, Litvinchuk et al. (2012) green triangle symbols, Beukema et al. (2013) and Bogaerts et al. (2013) red triangle symbols. The 'S' stands for $28 \mathrm{~B}$. bufo populations from in and around Switzerland that were studied by Lüscher et al. (2001) while five other of their populations are shown by the 'I' symbol. Records from the present paper are shown by diamond symbols for museum material and open round symbols in France for genetic data; two French localities with $B$. bufo and B. spinosus genetic markers in sympatry are indicated by a black cross. The locality Erloy in Northern France where B. bufo and B. spinosus exclusive alleles of the gene POMC are found in sympatry is shown by the \# symbol. For Far-eastern B. bufo localities see Recuero et al. (2012) and for the range border of the B. bufo-B. spinosus - B. verrucosissimus group across Eurasia see Sinsch et al. (2009). 


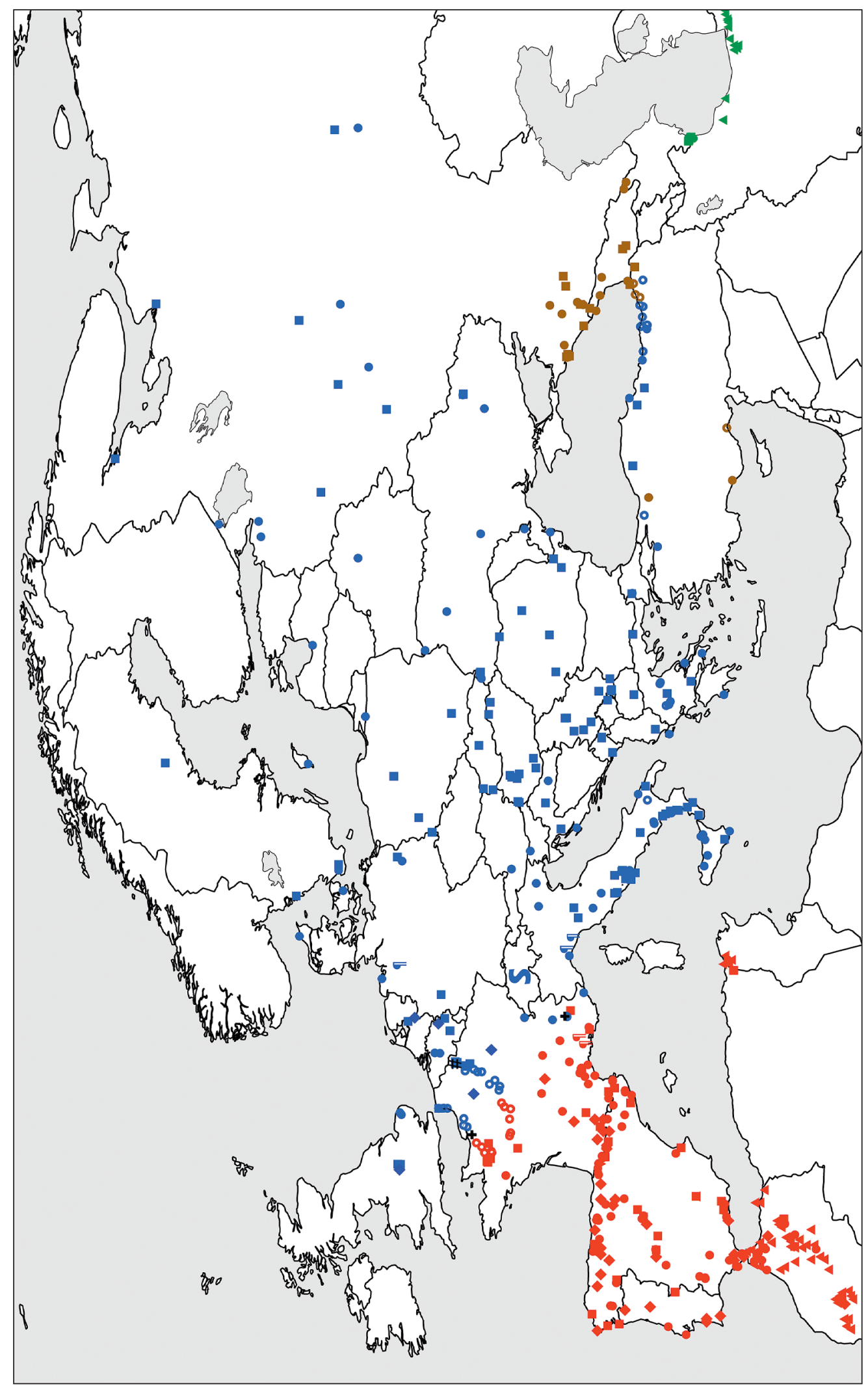

